\title{
Adipose tissue immune cells in obesity, type 2 diabetes mellitus and cardiovascular diseases
}

\author{
Anna Cinkajzlová1,2, Miloš Mráz²,3 and Martin Haluzík 2,3 \\ ${ }^{1}$ Experimental Medicine Centre, Institute for Clinical and Experimental Medicine, Prague, Czech Republic \\ ${ }^{2}$ Institute of Medical Biochemistry and Laboratory Diagnostics, First Faculty of Medicine and General University Hospital, Charles University, Prague, \\ Czech Republic \\ ${ }^{3}$ Diabetes Centre, Institute for Clinical and Experimental Medicine, Prague, Czech Republic
}

Correspondence should be addressed to M Haluzik: mhalu@lf1.cuni.cz

\begin{abstract}
Immune cells are an inseparable component of adipose tissue intimately involved in most of its functions. Physiologically, they regulate adipose tissue homeostasis, while in case of adipose tissue stress, immune cells are able to change their phenotype, enhance their count and subsequently contribute to the development and maintenance of local adipose tissue inflammation. Immune cells are an important source of inflammatory cytokines and other pro-inflammatory products that further influence not only surrounding tissues but via systemic circulation also the whole organism being thus one of the main factors responsible for the transition from simple obesity to associated metabolic and cardiovascular complications. The purpose of this review is to summarize current knowledge on different adipose tissue immune cell subsets and their role in the development of obesity, type 2 diabetes mellitus and cardiovascular diseases.
\end{abstract}

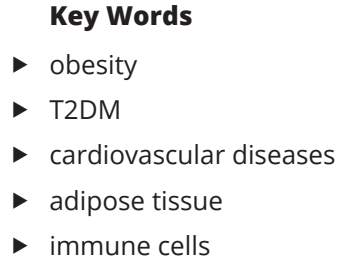

Journal of Endocrinology (2021) 252, R1-R22

\section{Introduction}

Adipose tissue (AT) is an active organ dynamically reacting to the metabolic status of the organism. The whole-body AT can be divided into two major - the subcutaneous (SAT) and the visceral (VAT) - and several minor AT depots (epicardial, perivascular, perirenal, intraosseous, intraarticular, etc.). VAT, which is present mainly in the mesentery and omentum, contains a lower amount of preadipocytes and a higher count of metabolically more active and insulin-resistant adipocytes along with a richer blood supply and innervation than SAT. It also exerts a higher capacity for glucose and lipid uptake and production of free fatty acids, has more receptors for glucocorticoids and androgens and contains more immune cells (Ibrahim 2010). Excessive accumulation of VAT phenotypically presented as android obesity is associated with higher metabolic risk and the development of insulin resistance, arterial hypertension, type 2 diabetes mellitus (T2DM) and cardiovascular diseases (Samsell etal. 2014). One of the main mechanisms responsible for the transition from simple obesity to subsequent cardiometabolic complications is the development of, at first, local and then systemic lowgrade inflammation characterized by accumulation of inflammatory immune cells and increased production of pro-inflammatory factors in obese AT, with VAT being again significantly more prone to these effects than SAT (Castro et al. 2016). Furthermore, AT immune cell changes are potentially associated with higher risk of gestational diabetes mellitus and preeclampsia in pregnant women further confirming the role of AT inflammation and its immune cells in obesity-associated morbidity (Huda et al. 2017, Cinkajzlova et al. 2020).

Interestingly, while obesity is primarily associated with phenotypic and functional changes of AT immune cells, recent results from single-cell RNA sequencing 
techniques showed the existence of several adipocyte progenitor cell subtypes specialized in different functions including thermogenesis, lipid storage and adipokine secretion as well as more subtypes of adipocytes. These adipocyte subtypes, differing in key adipocyte functions such as leptin and adiponectin expression, along with their precursors seem to collectively mediate the multiple diverse functions of AT and contribute to its physiologic and pathophysiologic milieu (Min et al. 2019).

\section{The role of immune cells in adipose tissue physiology}

Immune cells in AT serve several functions. Physiologically, they contribute to tissue homeostasis by being involved in tissue repair and apoptosis of damaged or infected cells as they react to damage-associated molecular patterns (DAMPs) such as nuclear or cytosolic proteins and to pathogen-associated molecular patterns (PAMPs) such as bacterial lipopolysaccharide or peptidoglycans. Effective sensing of DAMPs and PAMPs through pathogen recognition receptors rapidly induces immune responses via the activation of complex signaling pathways (Kumar et al. 2011, Roh \& Sohn 2018). This process is accompanied by cell metabolic changes and production of different cytokines and other pro-inflammatory factors such as free radicals, nitric oxide and others (Pearce \& Pearce 2013).

Immune cell subsets from both main lines - myeloid and lymphoid - can be found in AT, albeit with different frequency and significance for the development of AT inflammation with the most important being macrophages and $\mathrm{Tlymphocytes}$ and their different phenotype subtypes.

\section{Myeloid cells in adipose tissue}

Myeloid cells consist of cells of monocyte-macrophage line, granulocytes, which are further divided into eosinophils, basophils and neutrophils, and some subsets of dendritic cells (DCs), which are crucial for innate immunity. Neutrophils are the most abundant leukocyte subset in mammals and are responsible for pro-inflammatory and antiviral responses. Monocytes are large mononuclear leukocytes involved in the inflammation and clearance of pathogens. They are able to differentiate into macrophages and DCs (Stegelmeier et al. 2019). According to CD14 and CD16 surface expression, monocytes are divided into three subsets - classical (85\% of monocytes), non-classical (10\% of monocytes) and intermediate monocytes. Classical monocytes are professional phagocytes producing anti-and pro-inflammatory cytokines and reactive oxygen species and engulfing native LDL particles, while non-classical monocytes are weaker phagocytes, engulf oxidized LDL particles and produce pro-inflammatory cytokines (Belge et al. 2002, Ziegler-Heitbrock 2007, Mosig et al. 2009).

\section{Macrophages}

The most frequent immune cells in AT derived from the myeloid precursor are macrophages. In general, macrophages are phagocytic cells defending the organism against foreign pathogens and their substances such as lipopolysaccharide, as well as cancer, damaged endogenous cells and cellular debris. They exist either in tissue-resident form (e.g. Kupffer cells in the liver) or can be recruited and developed from blood monocytes in response to cytokine production (Watanabe et al. 2019a). In AT, another source of macrophages might be preadipocytes, as suggested by in vitro studies (Cousin et al. 1999, Charriere et al. 2003). These preadipocyte-derived macrophages were shown to express antigens typical for both monocytes and macrophages and to exert anti-microbial and phagocytic activity (Cousin et al. 2001). Besides this, macrophages are also able to replicate and thus be their own source (Hashimoto et al. 2013, Yona et al. 2013) without any phenotypic changes (Sieweke \& Allen 2013). As demonstrated in in vitro studies (Athie-Morales et al. 2004, Mantovani et al. 2004, Iwakura \& Ishigame 2006), macrophages can exert two extremely polarized states termed M1 and M2. M2 macrophages represent the anti-inflammatory state characterized by the production of the interleukins (ILs) IL4, IL13 and IL10, while M1 macrophages are deemed pro-inflammatory and produce TNF $\alpha$, IL12 and IL23, regulating their own and T helper lymphocytes (Table 1). According to the initial hypothesis derived especially from rodent models (Gordon 2003, Gordon \& Taylor 2005), the anti-inflammatory M2 macrophages are present predominantly in lean subjects, where they help in keeping AT homeostasis and maintaining physiological insulin sensitivity (Odegaard et al. 2007). Long-term increase in body weight is associated with a transition to the pro-inflammatory M1 phenotype along with enhanced monocyte recruitment into AT. M1 macrophages also represent an important source of reactive oxygen species and nitric oxide (Mantovani et al. 2004), which may contribute to the development of AT fibrosis via mitochondrial dysfunction of preadipocytes and activation of matrix metalloproteinase 9. Macrophages actively communicate with other immune cell types, especially with Th lymphocytes. As demonstrated before, M1 macrophages regulate mostly Th1 and Th17 cell response, while M2 macrophages regulate Th2 lymphocytes 
Table 1 Signature cytokines of adipose tissue immune cells and their role in obesity, type 2 diabetes mellitus and cardiovascular diseases.

\begin{tabular}{|c|c|}
\hline Cytokines & Source \\
\hline $\mathrm{TNF} \alpha$ & $\begin{array}{l}\text { Adipocytes, } \\
\text { macrophages } \\
\text { (M1/MMe), Th1 } \\
\text { lymphocytes, } \\
\text { NK cells }\end{array}$ \\
\hline
\end{tabular}

IL1 $\beta$

IL6

IFN $\gamma$

Th1 cells, Tc cells, NK cells, NKT cells, M1 macrophages
IL1及: mediator of metabolic inflammation, represses insulin signaling, contributes to $\beta$-cell failure
Association with cardiovascular diseases

Induction of systemic inflammation and acute phase response

TNF $\alpha$ : correlates with the degree of adiposity and $\mathrm{HbA}_{1,}$, associated with insulin resistance and T2DM, reduces the expression of insulinregulated glucose transporter type 4 located in adipocytes and skeletal and cardiac muscles

IL6: supports both $\mathrm{M} 2$ and Th2 polarization or conversely M1 response in the presence of IFN $\gamma$, mediates macrophage-adipocyte crosstalk, increases lipolysis, suppresses adiponectin secretion, increases glycemia by suppressing glucose uptake by adipocytes, decreases hepatic insulin sensitivity and glycogen synthesis

Upregulates production of macrophage mediators, induces production of leukocyte adhesion molecules and chemokines, increases antigen-presenting capacity by macrophages and endothelial cells, disrupts cellular metabolism and energy expenditure, increases insulin resistance and negatively influences glucose tolerance

Inhibits adipogenesis, promotes IL6 production in differentiated adipocytes, increases in obesity and T2DM, impairs glucose uptake and insulin sensitivity, induces free radical production in diabetes

Downregulates TNF $\alpha$ production, inhibits expression of adhesion molecules and antigen presentation, controls tissue remodeling, improves insulin sensitivity and glucose transport

\section{TNFo: involved in}

atherosclerosis progression, stimulates interaction between leukocytes and the endothelium through upregulation of adhesion molecules, stimulates myocyte hypertrophy through generation of reactive oxygen intermediates in cardiac myocytes, induces ventricular remodeling

IL1及: increases nitric oxide synthesis leading to lower energy production and reduced myocardial contractility, stimulates post-infarction inflammatory response, involved in cardiac remodeling

IL6: progression of atherosclerosis by induction of endothelial dysfunction and lipoprotein oxidation, independent risk factor for coronary artery disease

Increases accumulation of myeloid cells in infarcted cardiac tissue, activates cardiac macrophages in ischemic myocardium, promotes atherosclerosis and increases plaque vulnerability

Contributes to atherosclerosis and plaque vulnerability, extracellular matrix remodeling through upregulation of angiotensin 2 type 1 receptor, increases in acute coronary syndrome Downregulates adhesion molecule expression on endothelial cells, protective during myocardium ischemia or reperfusion, low levels lead to development of extensive and unstable atherosclerotic lesions

Associated with higher cardiovascular risk in subjects with chronic kidney disease 
Table 1 Continued.

\begin{tabular}{|c|c|c|}
\hline Cytokines & Source & General functions \\
\hline IL5 & $\begin{array}{l}\text { M2 macrophages, } \\
\text { Th2 cells, Tregs, } \\
\text { mast cells, } \\
\text { basophils }\end{array}$ & $\begin{array}{l}\text { Homeostatic, anti- } \\
\text { parasitic and allergy } \\
\text { reactions }\end{array}$ \\
\hline
\end{tabular}

Associated with alternative development

IL4: improves insulin sensitivity and glucose tolerance by inhibition of adipogenesis and activation of lipolysis

IL13
IL13: improves insulin secretion, involved in glucose uptake and metabolism in skeletal muscle
Association with cardiovascular diseases

IL5: atheroprotective

role,facilitates recovery of cardiac function after myocardial infarction IL4: induces pro-inflammatory environments in vascular endothelium by overexpression of inflammatory mediators, increases vascular cell adhesion molecule 1 expression in vascular endothelium, promotes fibrotic tissue formation after myocardial infarction

IL13: inhibits progression of atherosclerosis, facilitates cardiac regeneration after myocardial infarction

IFN, interferon; IL, interleukin; MMe macrophages, metabolically activated macrophages; NK cells, natural killer cells; NKT cells, natural killer T cells; Tc cells, T cytotoxic cells; Th cells, T helper cells; TNF, tumor necrosis factor; Tregs, T regulatory cells; T2DM, type 2 diabetes mellitus.

(Mantovani et al. 2004). Apart from communication through cytokine production, macrophages and $\mathrm{T}$ lymphocytes are able to communicate through direct cell contact by CD154 (CD40 ligand) and CD40 antigens (Elgueta et al. 2009).

Nevertheless, currently, it seems that in vivo macrophages in AT show a rather mixed phenotype and functional heterogeneity termed as metabolically activated phenotype (MMe) (Zeyda et al. 2007, Li et al. 2010, Kratz et al. 2014, Martinez \& Gordon 2014). According to murine results (Coats et al. 2017), MMe macrophages under the control of toll-like receptor 2 (TLR2), NADPHoxidase-2 and MYD88 overexpress pro-inflammatory cytokines TNF $\alpha$, IL1 $\beta$ and IL6 promoting insulin resistance similarly to M1 macrophages, while also being capable to exocytose their lysosomes and clear dead adipocytes, thus limiting insulin resistance similarly to M2 macrophages. Furthermore, metabolic activation of macrophages is associated with the same surface markers as classical activation of M1 macrophages. MMe macrophages specifically overexpress ATP binding cassette subfamily A member 1, CD36 and Perilipin 2 regulated by p62 and peroxisome proliferator-activated receptor-gamma (Kratz et al. 2014). The complex role of macrophages and their derivates in AT inflammation is underscored by recent findings of foam cells - lipid-laden macrophages best known from atherosclerotic lesions - within AT, where they engulf the remains of dead adipocytes (Shapiro et al.
2013) or results from single-cell RNA sequencing describing a population of 'lipid-associated macrophages' in both murine and human VAT. In a mouse model, the proportion of these cells correlated with BMI, and the knockout of their signature gene (Trem2) lead to high-fat diet-induced obesity, insulin resistance and dyslipidemia (Jaitin et al. 2019). These cells similar to M1 macrophages contribute to inflammation by increased IL1 $\beta$, TNF, IL18, CXCL18 and -platelet-derived growth factor-beta production (Hildreth et al. 2021). To sum up, this macrophage plasticity with the absence of a fixed and static M1/M2 dichotomy might play an important role in the resolution of the actual needs of AT.

\section{Granulocytes}

Granulocytes (neutrophils, eosinophils and basophils) play an essential role during microbe-induced and sterile inflammation as they are the terminally differentiated short-lived phagocytes (Geering et al. 2013). Besides that, granulocytes can acquire the function of antigenpresenting cells for $\mathrm{T}$ lymphocytes under inflammatory and other pathological conditions (Lin \& Lore 2017). While eosinophils and basophils are involved in antiinflammatory reactions in lean AT, neutrophils act rather in obese AT, where they conversely support proinflammatory processes. Eosinophils are generally associated with Th2 responses involved in antiparasitic and allergic reactions with their primary cytokine being 
IL4 (Jacobsen et al. 2012). Neutrophils are the dominant population among granulocytes and represent one of the first responders during acute inflammation (Geering et al. 2013). In chronic inflammation, they are able to influence adaptive $\mathrm{T}$ cell immunity through their effect on DC priming and directly on $\mathrm{T}(\mathrm{CD} 4+)$ cells themselves (Minns et al. 2019). In lean subjects, the actions of neutrophils are suppressed and negatively regulated by adiponectin. Adiponectin inhibits superoxide generation through the regulation of NADPH oxidase (Magalang et al. 2006) as well as neutrophil apoptosis (Rossi \& Lord 2013b) and phagocytosis (Rossi \& Lord 2013a). Both basophils and mast cells synthetise heparin and histamine and express plasma membrane receptors that bind IgE with high affinity. They both play a crucial role in allergy and asthma (He et al. 2013). Basophils emerge from the bone marrow as mature cells, whereas mast cells are released in an immature form and are fully activated after transmigration into target tissues. Basophils mainly produce Th2 cytokines (IL4 and IL13), while mast cells produce both Th1 and Th2 cytokines (Marone et al. 1997, Geering et al. 2013).

\section{Lymphoid cells in adipose tissue}

Cells of the lymphoid line represent a heterogenous cell population involved in both innate and acquired immunity. They develop in bone marrow, thymus and spleen (Caspar-Bauguil et al. 2005). Blood lymphocytes are probably the only source of AT lymphocytes, which are recruited in response to cytokine production of stressed adipocytes and already present immune cells. In AT, blood lymphocytes undergo further maturation in response to tissue needs and actual cytokine milieu (Rocha et al. 2008). Thus, the whole spectrum of lymphocyte subtypes including T helper (Th) and cytotoxic cells, B cells, natural killer (NK), natural killer $\mathrm{T}$ (NKT) and $\gamma \delta$-T cells can be found in AT.

\section{T helper lymphocytes}

The group of Th lymphocytes consists of several specific T cell subpopulations including Th1, Th2, Th17 and Treg lymphocytes, which reciprocally develop under particular tissue cytokine production and all of which can be found within AT (Mills et al. 2000). According to a simplified concept, Th1 and Th17 lymphocytes represent the proinflammatory phenotypes prevalent in obese AT, while Th2 and Treg lymphocytes are considered anti-inflammatory and participate in AT homeostasis in lean subjects (Winer et al. 2009).
Th1 and Th17 cells are stimulated by IFN $\gamma$, IL12 and IL6 and are associated with M1 macrophage reactions, while Th2 and Treg cells are stimulated by IL2 and IL4 and are connected with M2 macrophages (Odegaard et al. 2007, Tiemessen et al. 2007). Th1 lymphocytes are a significant source of INF $\gamma$ and IL2 thus stimulating their own production (Martinez \& Gordon 2014). As seen in rodent models (Surendar et al. 2019), adiponectin reduces IFN $\gamma$ and IL17-positive $\mathrm{T}$ cells and dampens the differentiation of naïve $\mathrm{T}$ cells into Th1 and Th17 populations. Th2 lymphocytes produce anti-inflammatory cytokines such as IL4, IL5, IL10 and IL13. They also stimulate IgE production by B lymphocytes as well as eosinophil activation and M2 macrophage responses (Romagnani 1999, Berger 2000). Treg lymphocytes, similarly to Th2 lymphocytes, suppress Th1 and Th17 cell responses by inhibition of IFN $\gamma$ (Sojka \& Fowell 2011, Joller et al. 2014) and by stimulation of IL10 (Chaudhry et al. 2011). Both Th2 and Treg subsets are commonly found in lean AT, but their numbers decrease along with the increase of Th1 and Th1 subsets during the development of obesity and insulin resistance (Feuerer et al. 2009).

\section{T cytotoxic lymphocytes}

T cytotoxic (Tc) lymphocytes are cells involved in acquired immunity with the ability to induce apoptosis of infected, damaged or tumor cells by perforin (Prf) and granzyme production. Tc lymphocytes express CD8 antigen and are activated by antigens presented by major histocompatibility complex class I (MHC-I). Their activation is enhanced by cytokine production (notably IL12 and IL18) and can also be triggered by $\mathrm{T}$ cell receptor-independent mechanisms (Henry et al. 2008, Freeman et al. 2012). Similarly to Th1 lymphocytes, Tc lymphocytes are increased in obese AT, where they support macrophage accumulation (Jiang et al. 2014), whereas their depletion is associated with enhanced beige adipogenesis as shown in murine experiments (Moysidou et al. 2018). The Tc lymphocyte population also consists of more subpopulations with Tc2 subpopulation producing the anti-inflammatory IL4 and IL5 cytokines, while Tc1 cells being characterized by IFN $\gamma$ production (Dobrzanski et al. 2004).

\section{B lymphocytes}

B lymphocytes are cells of acquired immunity and are the only cell population capable of producing specific antibodies. Besides that, B lymphocytes are antigenpresenting cells for Th lymphocytes (Wortis et al. 1995) and a source of different cytokines (Nishimura et al. 2013). All these three mechanisms were suggested to take part in 
the regulation of AT inflammation and insulin resistance (Winer et al. 2011). The B cell population consists of B-1 and B-2 cell subpopulations with reciprocal functions. B-1 cells, predominantly found in the peritoneal and pleural cavities, represent long-lived self-renewing cells, which, as a part of innate-like immunity, produce antibodies toward bacterial and self-antigens promoting a rapid response to infection and clearing of apoptotic cells. B-2 cells, which represent the majority of all B lymphocytes, are short-lived circulating cells producing specific antibodies and collaborating with Th lymphocytes (Wong et al. 2019, Mahajan et al. 2020). As seen in murine models, the B-1 to B-2 cell ratio varies between AT departments - being highest in omental VAT $(\approx 0.8: 1)$ and lowest in SAT, also in comparison with perivascular AT (PVAT; $\approx 0.3: 1)$, epidydimal VAT $(\approx 0.3: 1)$ and brown AT $(\approx 0.2: 1)$ (Srikakulapu \& McNamara 2020). Nevertheless, B cell accumulation was shown to promote inflammation, while their global depletion attenuated high-fat dietinduced AT inflammation and insulin resistance (Winer et al. 2011).

\section{Natural killer cells}

NK cells belong to the group of innate immune cells and induce apoptosis of cells infected by viruses or transformed by cancer (Smyth et al. 2005). In AT, NK cells are able to communicate with adipocytes by direct cell contact through the NK cell activating receptor 1 (NCR1) (Wensveen et al. 2015). NK cells also induce the differentiation of naive Th cells into Th1 cells (as they represent an early source of IFN $\gamma$ ) (Martin-Fontecha et al. 2004) and provide cross-presentation of antigens to Tc lymphocytes through DCs (Deauvieau et al. 2015). Singlecell RNA sequencing revealed that healthy SAT contains a unique NK cell subpopulation producing IFN $\gamma$ (Hildreth et al. 2021). As shown experimentally (O'Sullivan et al. 2016), these cells and their cytokine production could play an important role in the regulation of early phases of obesity development as they are active at the beginning of high-fat feeding directly in AT, where they likely produce the most IFN $\gamma$ in situ on a per cell basis of all AT cells and are necessary (and sufficient) to drive the pro-inflammatory macrophage polarization.

\section{Natural killer T cells}

NKT cells are lymphocytes positioned in between innate and acquired immunity that are capable of proinflammatory as well as anti-inflammatory cytokine production. They include three subpopulations: invariant NKT cells (iNKT, type I), diverse NKT cells (dNKT, type II) and NKT-like cells (Park et al. 2018). iNKT cells standardly reside in AT and can be activated by both professional and non-professional antigen-presenting cells (Huh et al. 2017). Of the three NKT lymphocyte subtypes, iNKT cells seem to have the greatest impact on the resolution of AT inflammation due to their ability to recognize lipid molecules loaded onto CD1d receptor of antigenpresenting cells by their semi-invariant T-cell receptor triggering anti-inflammatory cytokine secretion (Huh et al. 2017). dNKT cells are also able to distinguish some types of lipid molecules presented through CD1d (Patel et al. 2012) and possibly exacerbate obesity by controlling the VAT volume and insulin resistance as mice deficient in both iNKT and dNKT show higher weight gain and adipocyte size compared to mice lacking only iNKT cells (Satoh et al. 2012), while also developing hypertriglyceridemia and aggravated inflammation (Subramanian et al. 2018). On the other hand, this population might also have beneficial effects as transferring both iNKT or dNKT cells into obese mice induces transient weight loss and stabilizes glucose homeostasis (Hams et al. 2013).

\section{$\gamma \delta$-T cells}

$\gamma \delta$-T cells are a specific subpopulation of $\mathrm{T}$ cells that develop in the thymus and express a unique receptor composed of one $\gamma$-chain and one $\delta$-chain. Their activation is elicited mostly by innate signals subsequently triggering cytokine production and cytolytic reactions (Born et al. 2006). Activated $\gamma \delta-T$ cells enhance NK cell cytotoxicity through CD137 engagement, stimulate monocytes and macrophages and promote DC maturation further leading to Th and Tc lymphocyte activation (Leslie et al. 2002, Eberl et al. 2009, Maniar et al. 2010). As found in murine models (Mehta et al. 2015), $\gamma \delta$-T cells reside in lean AT and increase during diet-induced obesity promoting inflammation and insulin resistance through the regulation of other immune cells such as macrophages. Furthermore, AT-resident $\gamma \delta$-T cells regulate the production of IL33 from stromal cells through the secretion of IL17A, thereby controlling agedependent Treg expansion as well as core body temperature in response to environmental fluctuations. Potentially, IL17 produced by $\gamma \delta$-T cells could contribute to the Th17 response observed in obese subjects (Kohlgruber et al. 2018).

\section{Dendritic cells in adipose tissue}

DCs as professional antigen-presenting cells play a crucial role in the initiation of antigen-specific immunity and tolerance as they drive the maturation and polarization 
of naïve T cells through MHC complex class II alongside the exposure of appropriate membrane-bound signaling molecules and secretion of specific cytokines. As shown in mouse models (Wu et al. 2001), DCs can be differentiated from both myeloid and lymphoid common progenitor. They drive the regulation of pro-inflammatory as well as anti-inflammatory responses (Steinman 2012). Two major subtypes of DCs have been identified; CD11cpositive conventional (myeloid) DCs (cDCs) involved in the differentiation of CD4+ $\mathrm{T}$ cells and CD123-positive plasmacytoid DCs (pDCs) characterized by the production of type I interferon, activation of macrophages and antiviral defense (Tamura et al. 2005, Gilliet et al. 2008, Sundara Rajan \& Longhi 2016). As shown in both lean mice and humans (Bertola et al. 2012), their AT contains resident cDCs, which are capable of capturing and presenting antigens to Th lymphocytes in an antigen-specific manner leading to their differentiation - preferentially Treg cells and Th17 lymphocytes in a very low extent.

\section{The role of adipose tissue immune cells in obesity and T2DM}

In case of tissue stress induced by long-term overweight and obesity, immune cells probably at first react to changes in the expression profile of the hypertrophied adipocytes (typically increased leptin, TNF $\alpha$, IL6 and decreased adiponectin production) and try to regulate the commencing inflammation by changing their secretion and polarization profile. In the case of sustained tissue stress, original regulatory reactions apparently overshoot and immune cells themselves, under the influence of adipocyte-produced cytokines and chemokines, start to contribute to the inflammatory milieu (Fig. 1) (Lumeng et al. 2007, McLaughlin et al. 2014).

As suggested on the basis of mostly rodent studies, lean state is associated with a smaller number of immune cells in AT and their anti-inflammatory profile, while overweight and obesity are characterized by a higher proportion of immune cells with pro-inflammatory status (Weisberg et al. 2003, Bourlier et al. 2008, Lumeng et al. 2008). The lean AT immune cells consist mainly of M2 macrophages, Th2 and Treg lymphocytes, whereas obese AT is dominated by classically activated M1 macrophages, Th1 and Tc lymphocytes and NK cells (Table 2). Additionally, other immune cells such as basophils, eosinophils, Blymphocytes, NKT and DCs can be found in AT with varying frequencies and functions between lean and obese fat (Mraz \& Haluzik
2014, Cinkajzlova et al. 2017a). It is currently unclear, if a precise identification and phenotypization of AT immune cells might be used as a tool for the discrimination between different obesity subphenotypes. As determined by prospective epidemiological studies, metabolically healthy obese frequently become metabolically unhealthy leading to elevated risk of obesity-associated comorbidities (Echouffo-Tcheuguietal.2019). Formerly evaluated methods including determination of peripheral blood leukocyte subclasses aimed at discriminating subjects at potentially increased complication risk seem to be insufficient (Pecht et al. 2014). Therefore, immunophenotyping of AT immune cells might, in spite of its invasiveness, represent an alternative approach to stratifying obese individuals according to their risk profile or serve as a tool for predicting the effects of weight-reducing interventions including bariatric procedures on mitigating the complication risk.

Interestingly, loss of metabolic control and increase of inflammatory activity could be also associated with aging, which physiologically leads to immunosenescence (Lee et al. 2021). Immunosenescence is the term used for the decline in innate immunity (mainly in reduced neutrophil and macrophage activation and cytotoxic activity of NK cells) and dysregulated lymphocyte response (increase in anergic memory $\mathrm{T}$ cells, decline in naïve T cells, exhaustion of Th, Tc and B lymphocytes). Some hallmarks of obesityassociated changes overlap with immunosenescence, and obesity was proposed to accelerate aging (Perez et al. 2016), which is connected with higher AT abdominal and ectopic accumulation (Mancuso \& Bouchard 2019), organelle stress (Ghosh et al. 2016) and with accumulation of senescence cells secreting pro-inflammatory cytokines such as IL6, IL8 or TNFa (Coppe et al. 2008, Baker et al. 2011). According to experimental data (Shirakawa et al. 2016), obesity seems to contribute to immunosenescence by pro-inflammatory activation of immune cells passing through AT microvasculature or pro-inflammatory differentiation and proliferation of cells within AT. Both mechanisms might negatively influence the efficacy of the immune system.

\section{Adipose tissue myeloid cells in obesity and T2DM}

\section{Macrophages}

As described above, in lean subjects, AT was shown to contain a smaller number of predominantly M2 antiinflammatory macrophages (approximately $10 \%$ of total AT cells), while AT of obese individuals had substantially more macrophages (in extremely obese humans, AT macrophages can represent up to $40 \%$ of total AT cells (Weisberg et al. 2003)) 


\section{Obese adipose tissue}

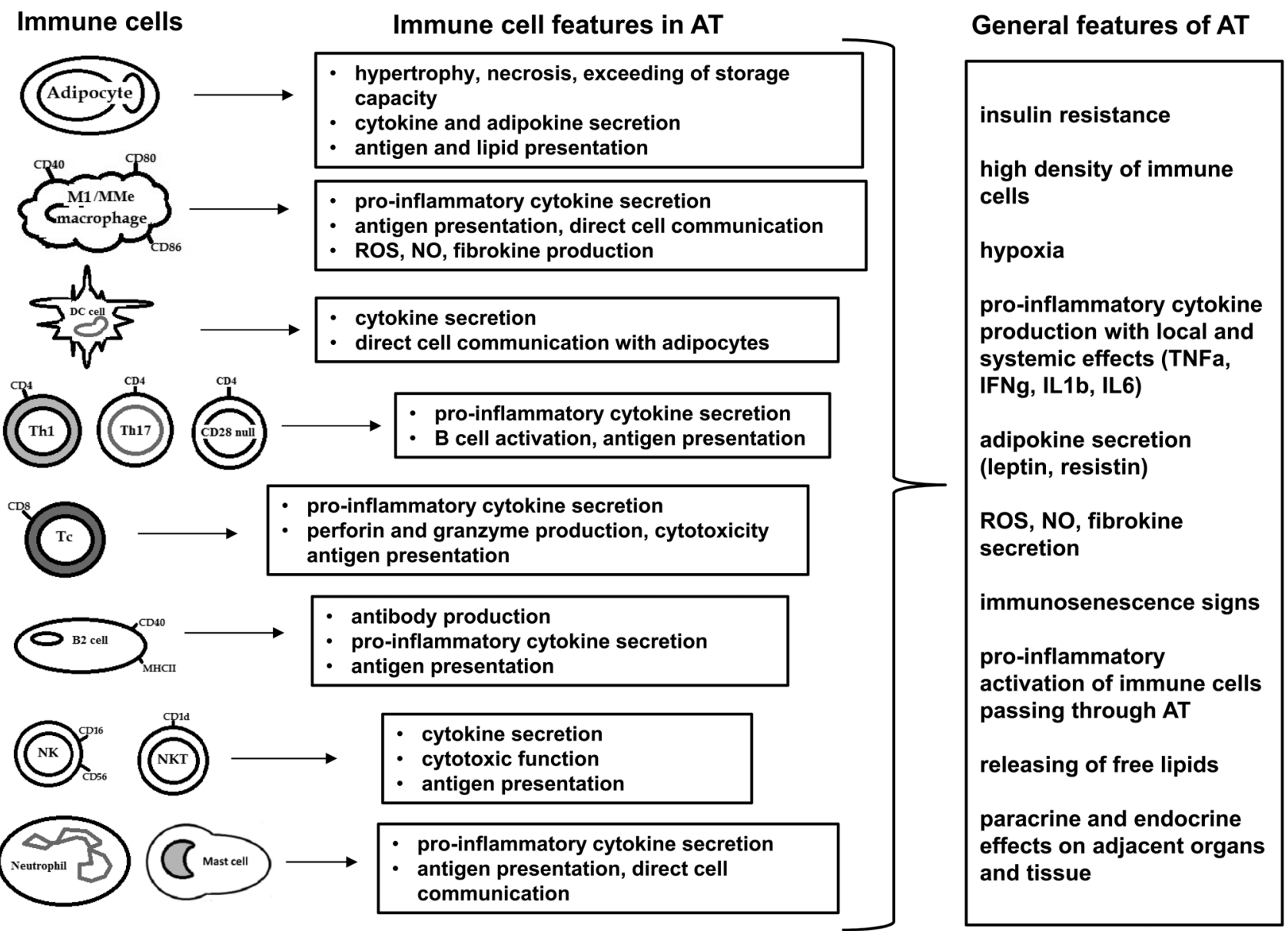

Figure 1

Immune cells and their main features in obese adipose tissue. Immune cells in adipose tissue react to tissue stress and hypoxia caused by obesity by their transmigration into tissue and pro-inflammatory reaction. CD, cluster of differentiation; IFN, interferon; IL, interleukin; MMe macrophages, metabolically activated macrophages; NK cells, natural killer cells; NKT cells, natural killer T cells; Tc cells, T cytotoxic cells; Th cells, T helper cells; TNF, tumor necrosis factor.

with mainly M1 polarization (or the above-described MMe phenotype). As referred above, macrophages of obese are a significant source of pro-inflammatory cytokines such as MCP-1, IL-6 or TNF- $\alpha$, which drive the development of AT inflammation (Kratzetal. 2014). One of the key playersin this process might represent the Wnt signaling pathway, which in adipocytes acts as a modulator of their development (Farmer 2005) and contributes to insulin resistance by supporting AT expansion and lipid accumulation (Fuster et al. 2015, Aamir et al. 2020). In macrophages, Wnt signalization could amplify their pro-inflammatory cytokine production through crosstalk with the TLR-4 pathway, which is activated by lipopolysaccharide and free fatty acids acting via NLRP3 (Nod-like receptor family pyrin domain containing) pathway (Rogero \& Calder 2018), as well as in an autocrine fashion through WnT5a expression and its Frizzled 5 receptor (Blumenthal et al. 2006, Catalan et al. 2014).

Nevertheless, the M1/MMe predominance within obese AT can be reversed by weight reduction as obese subjects after weight loss due to bariatric surgery showed lower macrophage count along with a shift back to the anti-inflammatory phenotype in both SAT and VAT (Aron-Wisnewsky et al. 2009, Cinkajzlova et al. 2017b). As shown in an experimental model (Li et al. 2010), phenotypic plasticity and AT macrophage polarization in obese subjects correlate well with the presence or absence of insulin resistance. Thus, insulin resistance might be directly improved by targeting macrophage polarization (Fujisaka et al. 2011). 
Table 2 The main differences in immune cells between lean and obese adipose tissue and their functions.

\section{Lean adipose tissue}

Macrophages

M2 macrophages

$>$ Anti-inflammatory actions

$>$ Homeostatic functions

$>$ Engulfment of free fatty acids

$>$ IL4, IL13, IL10 production

T lymphocytes

Th2 lymphocytes

Treg lymphocytes

$>$ Homeostatic functions

$>$ Anti-inflammatory actions

$>$ IL5, IL4, IL13, IL10 production

Tc2 lymphocytes?

> IL2, IL5 production

B lymphocytes

B1 lymphocytes

> IL10 production

$>$ Antibody (IgM) production

Non-T/B lymphocytes

iNKT cells

$>$ Anti-inflammatory actions

$>$ Direct cell communication with adipocytes through CD1c antigen

$>$ IL4, IL13, IL10 production

Other immune cells

Eosinophils

Basophils

$>$ IL4, IL13, IL10 production

Dendritic cells

$>$ Activation of Th1/Th17 responses
Obese adipose tissue

M1/MMe macrophages

$>$ Pro-inflammatory actions

$>$ Reactive oxygen species and nitric oxide production

$>\mathrm{TNF} \alpha, \mathrm{IL} 12, \mathrm{IL} 23$ production

Th1 lymphocytes

Th17 lymphocytes

$>$ Pro-inflammatory actions

$>\mathrm{IFN} \gamma, \mathrm{IL} 2, \mathrm{IL} 6, \mathrm{IL} 17$ production

Tc1 lymphocytes

$>$ Cytotoxic functions

$>$ Perforin and granzyme secretion

$>\mathrm{IFN} \gamma, \mathrm{TNF} \alpha, \mathrm{IL} 12, \mathrm{IL} 18$ production

B2 lymphocytes

$>$ Antibody (IgG) production

$>$ Antigen presentation to Th1 lymphocytes

$>$ IL6 production

NK cells

$>$ Induction of cell death

$>$ Cytotoxic functions

$>\mathrm{IFN} \gamma$, TNF $\alpha$ production

Neutrophils

Mast cells

$>$ IL1 $\beta$, IL17 production

Dendritic cells

$>$ Activation of Th17 responses

$>$ Macrophage recruitment

$>$ IL6, TGF $\beta$, IL23 production

IFN, interferon; IL, interleukin; MMe macrophages, metabolically activated macrophages; NK cells, natural killer cells; NKT cells, natural killer T cells; Tc cells, T cytotoxic cells; Th cells, T helper cells; TNF, tumor necrosis factor; Treg, T regulatory cells; T2DM, type 2 diabetes mellitus.

\section{Granulocytes}

In a mouse model, high-fat diet induced eosinophil accumulation in perigonadal white AT. Furthermore, adipocytes promoted the migration of eosinophils and likely also their survival through the expression of IL-3, IL-5 and granulocyte-macrophage colony-stimulating factor. Eosinophil-deficient mice showed impaired glucose tolerance and adipocyte maturation, impairment of energy metabolism and increased inflammatory response (Lee et al. 2018). Eosinophil recruitment into AT might also be regulated by long-lived type 2 innate lymphoid cells (Nussbaum et al. 2013). Eosinophils are capable of IL-4 and other type 2 cytokine production contributing to M2 polarization that results in fat browning through tyrosine hydroxylase expression and catecholamine production (Qiu et al. 2014). On the other hand, a mere presence of eosinophils in AT is insufficient to alter metabolic health (Bolus et al. 2017).
Obesity is associated with increased number of neutrophils in blood, with their activation being also increased (Nascimento et al. 2010, Xu et al. 2015). In lean mice, lipolysis of adipocytes leads to neutrophil accumulation in AT prior to macrophage infiltration, with subsequent neutrophil IL-1 $\beta$ production (Watanabe et al. 2019b). Another murine study (Elgazar-Carmon et al. 2008) confirmed that neutrophils transiently infiltrate intraabdominal AT early (3 and 7 days) after high-fat feeding, where they directly interact with adipocytes (through CD11b and ICAM-1). In humans, neutrophils probably also accumulate in AT during weight gain, while bariatric surgery induces a neutrophil decrease in both SAT and VAT (Garcia-Rubio et al. 2018). Neutrophils could contribute to IL-17 production thus supporting Th17 lymphocyte immune responses (Lin et al. 2011).

Obese subjects (both humans and mice) have increased amount of mast cells in white AT compared to
(C) 2021 Society for Endocrinology Published by Bioscientifica Ltd. Printed in Great Britain 
lean individuals, and their deficiency or pharmacological stabilization in mice reduced body weight gain and levels of inflammatory cytokines and proteases in serum and white AT along with improving glucose homeostasis and energy expenditure. Furthermore, mast cells contribute to white AT angiogenesis, associated cell apoptosis and cathepsin activity (Liu et al. 2009). Heparin secreted from stimulated cells may induce uptake of (modified) LDL by macrophages via scavenger receptor-mediated phagocytosis (Lindstedt et al. 1992). It was also suggested that mast cells and basophils possibly react directly with LDL through their own receptors (Virgolini et al. 1995). Surprisingly, bariatric surgery in obese humans was associated with an increase in mast cells in both SAT and VAT (Garcia-Rubio et al. 2018).

\section{Adipose tissue lymphoid cells in obesity and T2DM}

\section{T helper lymphocytes}

In diet-induced obese (DIO) mice, VAT Th1 lymphocyte population was shown to increase together with growing overweight and obesity, while other subpopulations were static (Winer et al. 2009). Th1 population was also able to produce more INF- $\gamma$ (Rocha et al. 2008). In contrast, Th2 lymphocytes were suggested to suppress the effects of obesity and insulin resistance as demonstrated by their transplantation into AT of DIO mice (Winer et al. 2009). In obese T2DM subjects, increased circulatory Th1 and Th17 lymphocytes positively correlated with HOMA index of insulin resistance, leptin and insulin levels (Pacifico et al. 2006) and negatively with HDL cholesterol, respectively (Zeng et al. 2012). In experimental animals (Feuerer et al. 2009), Treg lymphocytes were enriched in the abdominal fat of lean subjects, while their number was reduced in insulin-resistant models.

\section{T cytotoxic lymphocytes}

Tc lymphocytes that accumulate in obese AT bear the Tc1 phenotype and produce IFN- $\gamma$, IL-12 and IL-18 that contribute to a pro-inflammatory milieu (Jiang et al. 2014). Ablation of these cells reduced $T$ cell accumulation, activation and proliferationin ATand protectedfrominsulin resistance. According to murine results (Nishimura et al. 2009), Tc lymphocytes precede macrophage accumulation, and their depletion lowers macrophage infiltration into AT and ameliorates systemic insulin resistance. The percentage of Tc lymphocytes was shown to be higher in VAT compared to SAT and was associated with higher caspase- 1 activity leading to IL- $1 \beta$ and IL-18 production, respectively (Koenen et al. 2011). Interestingly, caspase-1 is also activated by free fatty acids which by triggering the
NLRP3 pathway initiates the formation of inflammasome and cleavage of pro-caspase-1 into active caspase (Wu et al. 2020). IL-18 in combination with IL-12 and IL-1 $\beta$, which are also increased in obese AT, participate in increased IFN- $\gamma$ production by Tc lymphocytes further leading to the activation of M1 macrophages and stimulation of inflammation (McDonnell et al. 2012). Surprisingly, Tc-derived Prf- 1 seems to play a protective role as Prf-1 null mice placed on high-fat diet showed increased body weight, adiposity and insulin resistance compared with WT littermates indicating that Prf- 1 might be a possible regulator of early body size and growth (Revelo et al. 2015). Besides that, Prf-1 null mice showed higher accumulation of IFN- $\gamma$-producing T lymphocytes and M1 macrophages in VAT further suggesting Prf to be involved in homeostatic regulation of $\mathrm{T}$ cells and in macrophage infiltration into AT. The role of granzyme is not precisely known, although it might contribute to inflammation by pro-inflammatory cytokine production (Metkar et al. 2008). Furthermore, single-cell RNA sequencing technique revealed that AT of obese subjects contains a subpopulation of CCL5+ Tc lymphocytes positively correlating with the degree of obesity and producing metallothionein (Vijay et al. 2020). Metallothionein seems to prevent the manifestation of obesity-related diseases through suppression of superoxide production, endoplasmic reticulum stress and associated damage (Sato et al. 2013).

\section{B lymphocytes}

As shown in DIO mice (Winer et al. 2011), during obesity, B cells infiltrate VAT (starting at 4 weeks of high-fat diet), exhibit maturation in correlation with the development of insulin resistance (without change in proportion between B cell subtypes), produce antibodies supporting inflammation (increase of Ig2c and decrease of $\operatorname{IgA}$ ) and contribute to $\mathrm{T}$ lymphocyte infiltration. IgM production by protective B-1 cells in murine VAT reduced cytokine production by M1 macrophages and ameliorated AT inflammation, insulin resistance and systemic glucose intolerance, while adoptive transfer of B-2 cells into VAT promoted metabolic dysfunction. B-2 cells probably produce pro-inflammatory cytokines (DeFuria et al. 2013) and promote insulin resistance through the secretion of leukotriene B4 (Ying et al. 2017). Furthermore, B-1 (CD20+CD27+CD43+) cells and IgM antibodies were also identified in human VAT, where they inversely correlated with inflammation and insulin resistance in obese subjects (Harmon et al. 2016). Similarly, reduction of B regulatory cells producing the anti-inflammatory IL-10 was identified in both obese mice and humans (Nishimura et al. 2013), 
and this reduction was possibly associated with Th1/ Th17 cytokine (IFN- $\gamma$, IL-17) increase (Garcia-Hernandez et al. 2018).

\section{Natural killer cells}

Obesity is associated with NK cell accumulation in AT (while their cytotoxic function remains unchanged) and increased NCR-1 expression on adipocytes (Wensveen et al. 2015). NK cells contribute to inflammatory reactions by increased production of IFN- $\gamma$ and TNF- $\alpha$, which support M1 macrophage polarization (Lee et al. 2016). Accumulation of NK cells was found to be increased in human VAT in obesity (Wouters et al. 2020), while in mice AT, NK cell depletion was associated with better insulin sensitivity and macrophage reduction (Lee et al. 2016). In contrast to Tc lymphocyte-produced Prf-1, NK-produced Prf-1 possibly does not have any regulatory effects on glucose homeostasis (Revelo et al. 2015).

\section{Natural killer T cells}

Resident iNKT cells represent $1-20 \%$ of the resident $T$ lymphocytes in lean AT, while obesity and high caloric intake reduce their population (Lynch et al. 2009, 2012, Schipper et al. 2012). In obese AT, iNKT cells are activated by lipids presented by adipocytes and produce IL-4, IL-10 and IL-2 cytokines driving the anti-inflammatory (M2 macrophage, Treg and Th2 lymphocyte) response (Park et al. 2018), but their number significantly declines in parallel with growing inflammation (Lynch et al. 2012). The protective role of iNKT cells was also confirmed by experiments with CD1d deletion in mice models leading to aggravated AT inflammation and insulin resistance (Huh et al. 2017).

\section{$\gamma \delta$-T cells}

In several murine studies (Zuniga et al. 2010, Mehta et al. $2015)$, the absence of $\gamma \delta$-T cells was associated with either no difference or a decrease in high-fat diet-induced insulin resistance with partial depletion of $\gamma \delta$-T cells showing no protection in this regard. In contrast, reduction of $\alpha \beta / \gamma \delta-T$ cell ratio (achieved by transgenic overexpression of PPAR- $\beta$ receptor leading to a partial depletion of $\alpha \beta$-T cells) partially protected the animals from high-fat diet-induced weight gain and decreased insulin resistance and liver steatosis independently of animal weight (Le Menn et al. 2019). $\gamma \delta$-T cells were also shown to have a crucial role in promoting sympathetic innervation of local AT, ablation of which was associated with defective thermogenesis and the development of obesity (Hu et al. 2020). In another study, mice lacking $\gamma \delta$-T cells had impaired glucose homeostasis, while ketogenic diet expanded their AT pool which was associated with restrained inflammation. In contrast, longterm ad libitum ketogenic diet depleted AT $\gamma \delta$-T cells and caused obesity and metabolic derangements (Goldberg et al. 2020).

\section{Dendritic cells}

The role of DCs in regulating inflammation in AT seems to be dependent on the actual tissue metabolic state. In lean animals, cDCs promote an anti-inflammatory state and delay the onset of obesity-induced chronic inflammation and insulin resistance (Macdougall et al. 2018), while longterm overnutrition induces a pro-inflammatory switch of cDCs resulting in activation of Th1 and Th17 cell responses (Bertola et al. 2012, Chen et al. 2014). The presence of DCs, which locally increase in murine AT during high-fat diet, seems to be essential for macrophage recruitment and their subsequent activation (Stefanovic-Racic et al. 2012, Cho et al. 2016).

Besides, a minor subpopulation of myeloid DCs with Prf-containing granules might possibly be involved in the regulation of body weight and development of the metabolic syndrome through their control over inflammatory $\mathrm{T}$ lymphocytes (Zlotnikov-Klionsky et al. 2015). Interestingly, subjects with T2DM showed increased amounts of pDCs in SAT and even more in EAT relative to non-diabetic subjects regardless of the presence of obesity (Mraz et al. 2019a), while no such changes were seen in cDCs. Single-cell RNA sequencing revealed three populations of cDCs (cDC1, cDC2A and $\mathrm{CDC} 2 \mathrm{~B}$ ) in SAT human samples with thus far unknown roles, although activation of Wnt signalization and tolerogenic programs in AT have been proposed. One population (CDC2B) might also trigger tissue inflammation (Hildreth et al. 2021). Besides the Wnt pathway, IL1 $\beta$ production could be increased by priming NLRP3 inflammasome formation through TLR4 under the exposition to free fatty acids, similarly to macrophages or Tc lymphocytes (Reynolds et al. 2012).

\section{The role of adipose tissue immune cells in cardiovascular diseases}

As evidenced by the association of obesity and T2DM with cardiovascular complications, AT and immune cell changes seem to have an eminent role in the development 
of cardiovascular diseases (Fig. 2). For instance, EAT, whose biological characteristics are similar to VAT, is a potentially important source of inflammatory cytokines that affect surrounding cardiac tissues in autocrine, paracrine and endocrine manner thus contributing to chronic inflammation and myocardium damage (Guzzardi \& Iozzo 2011). As shown before (Cheng et al. 2008), TNF- $\alpha$, IL1 $\beta$ and IL6 tissue levels are higher in patients with coronary artery disease (CAD) compared to non-CAD patients, and their actions are linked to the development or progression of cardiovascular diseases (Ferrari 1999, Volpato et al. 2001, Vicenova et al. 2009). Similarly, PVAT adjacent to human atherosclerotic arteries is more inflamed than PVAT adjacent to non-atherosclerotic vessels (Henrichot et al. 2005), and its thickness around coronary arteries has been associated with coronary artery calcification and increased CVD risk (de Vos et al. 2008).

\section{Myeloid cells in cardiovascular diseases}

\section{Macrophages}

Human immunochemistry studies (Hirata et al. 2011, Vianello etal. 2016) have shown that EAT macrophages have M1 polarization in patients with $\mathrm{CAD}$, and the percentage of these cells is higher compared to patients without CAD, in which M2 macrophages predominate. This more proinflammatory state is accompanied by increased TNF $\alpha$ and decreased adiponectin expression. It is a question if vitamin D supply associating with positive M1 into M2 macrophage transition in EAT of swine could have also beneficial effect
- TNFa, IL1b and IL6 cytokine secretion

- antigen presentation

- reactive oxide species and nitric oxide production
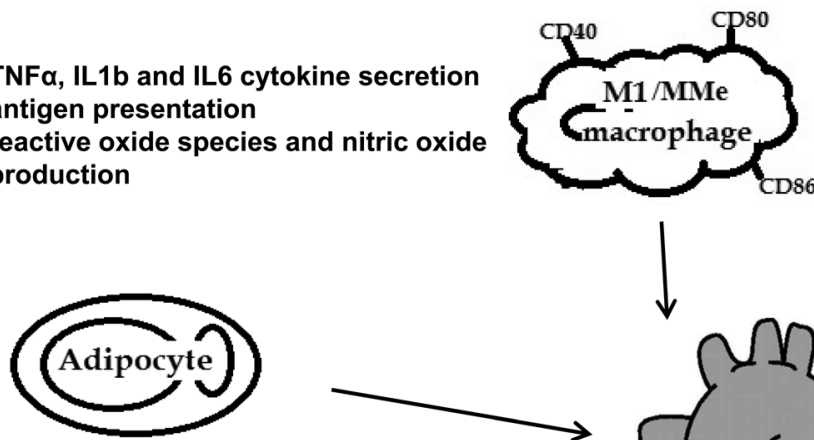

- cytokine (TNFa, IL1b) secretion

- adipokine production

- antigen and lipid presentation

- necrosis of hypertrophic adipocytes

- lipid release into extracellular space

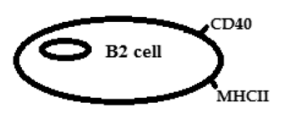

- antibody production

- cytokine secretion

\section{- antigen presentation

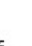

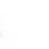
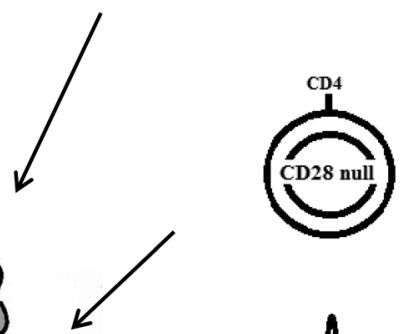

- IFNg cytokine secretion
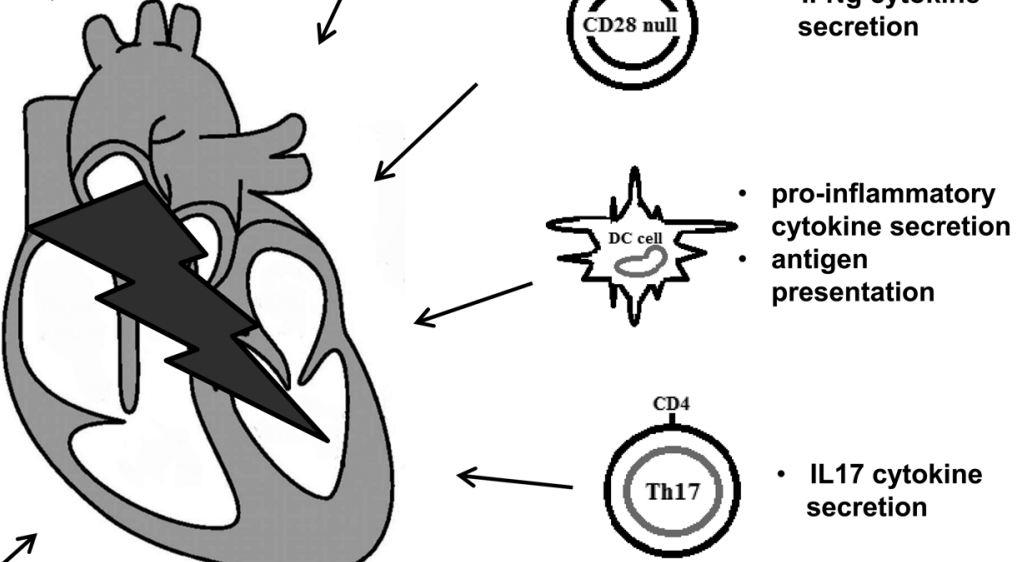

- IFNg cytokine secretion

- cytotoxic function

- antigen presentation

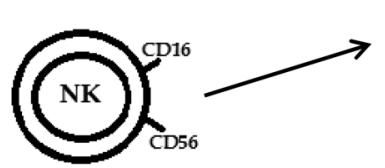

antigen presentation
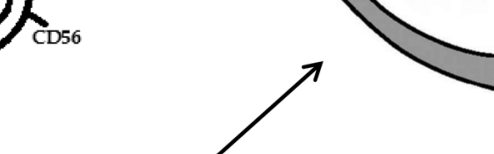

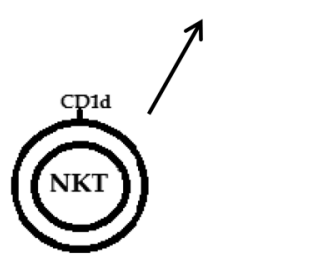

- perforin and granzyme production

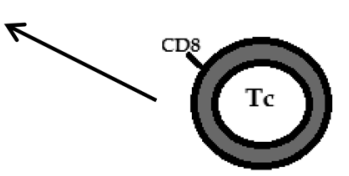

- IFNg,TNFa cytokine secretion

- perforin and granzym production, cytotoxic function

- antigen presentation

Figure 2

Major immune cell types associated with cardiovascular risk and their main functions in adjacent adipose tissue depots or atherosclerotic plaques. Although associations between $\gamma \delta$-T cells, dendritic cells, eosinophils and neutrophils and cardiovascular risk have also been suggested, their significance and functions are still unclear. CD, cluster of differentiation; IFN, interferon; IL, interleukin; MMe macrophages, metabolically activated macrophages; NK cells, natural killer cells; NKT cells, natural killer T cells; Tc cells, T cytotoxic cells; Th cells, T helper cells; TNF, tumor necrosis factor. 
during coronary intervention in human (Gunasekar et al. 2018). Besides, macrophage content in PVAT is positively related to the size and characteristics of the atherosclerotic plaque (its lipid core, calcification, collagen and smooth muscle cell content) (Verhagen et al. 2012), and it is also greater near unstable atherosclerosis plaques as compared with stable lesions and positively correlates with the percentage of coronary artery obstruction (Farias-Itao et al. 2019). Interestingly, the number of PVAT macrophages in subjects with CAD was shown to be similar to individuals with dilated cardiomyopathy (Kralova Lesna et al. 2015). Furthermore, macrophages in pericoronary AT can store oxidized LDL and HDL irrespective of the presence of atherosclerosis, while during its progression, they are able to migrate into the coronary intima and contribute to plaque growth and maturation (Uchida et al. 2017).

\section{Granulocytes}

Although evidence about differences in (blood) eosinophils in association with CAD is ambiguous (Verdoia et al. 2015, Gao et al. 2019), a rather positive role of AT eosinophils in protection against atherosclerosis seems plausible given their actions in obesity. However, eosinophil degranulation was shown to be higher in subjects with acute CAD; therefore, their exact function in the development of CAD needs further assessment (Niccoli et al. 2015).

Data about the association between AT neutrophils and cardiovascular riskarelimited. In obese females, neutrophils were shown to accumulate in the microvasculature of AT, and their presence positively correlated with BMI and diastolic blood pressure. Similarly, vascular inflammation (evaluated as expression of activated nuclear factor kappaB and cyclooxygenase-2) positively correlated with BMI (Leik \& Walsh 2004, Shah et al. 2010). Neutrophils adhere to the endothelium of white AT and are not present in AT parenchyma, suggesting that in vivo they do not transmigrate into the tissue like other immune cells or that their transmigration is limited (Rouault et al. 2013). Nevertheless, neutrophils are potential contributors to atherosclerotic plaque ruptures (Ionita et al. 2010).

In subjects with acute $\mathrm{CAD}$, higher basophil activation (Niccoli et al. 2015) and blood count (Soylu et al. 2014) was found, which might be decreased by statin treatment resulting in a reduction of arterial wall stiffness (Toyama et al. 2012). Mast cells found in the heart were reported to participate in the development of atherosclerosis, coronary inflammation and cardiac ischemia (Kritikou et al. 2016). Moreover, mast cells showed increased prevalence in atherosclerotic lesions and were associated with plaque microvessel density (Willems et al. 2013). Nevertheless, a causal relationship between AT mast cells and basophils and cardiovascular risk has not been confirmed yet.

\section{Lymphoid cells in cardiovascular diseases}

\section{T helper lymphocytes}

As shown in carotid artery plaques of patients with recent stroke or transient ischemic attack, atherosclerotic plaques are rich in activated Th1 and Th17 lymphocytes (Fernandez et al. 2019). Circulatory Th1 lymphocytes are associated with increased prevalence of acute coronary artery syndrome and atherosclerosis (Methe et al. 2005), while Th2 and Treg responses reduce the risk of myocardial infarction and stroke (Han et al. 2007, Engelbertsen et al. 2013). Interestingly, the protective role of Th2 cells seems to be more prominent in females (Engelbertsen et al. 2013). In humans, EAT and SAT density of Th lymphocytes was not influenced by CAD, although the allover T lymphocyte population was higher in CAD subjects as compared with controls without CAD (Mraz et al. 2019b). As shown by a multi-ethnic study of atherosclerosis (Olson et al. 2013), memory CD4+ $\mathrm{T}$ cells are positively related to arterial intimal media thickness, while naïve $\mathrm{T}$ cells displayed inverse correlation. Furthermore, higher amount of circulating CD4+ T memory cells was associated with coronary artery calcification. According to rodent results (Bansal et al. 2017), Th lymphocyte expansion in circulation, as well as cardiac and lymphatic tissue, is seen in chronic ischemic heart failure with a predominance of Th 2 vs Th 1 and Th 17 vs Treg cells in the failing myocardium. The function of Th17 in cardiovascular diseases is still unclear, although its master cytokine IL17A expression is increased in atherosclerotic lesions. IL17A is also positively associated with inflammation and plaque vulnerability and negatively with IL10 expression (Erbel et al. 2011). IL17 was also shown to be produced concomitantly with the Th1 signature cytokine IFN $\gamma$ in coronary artery plaques resulting in synergistical increase of pro-inflammatory responses by vascular smooth muscle cells (Eid et al. 2009). CD28 null (CD28-CD4+) T lymphocytes are another subset of $\mathrm{T}$ cells that starts emerging in the context of increased cardiovascular risk. These cells producing IFN $\gamma$ were found in subjects with acute coronary syndrome, unstable angina and myocardial infarction, where their presence was associated with increased mortality and event recurrence (Liuzzo et al. 1999, 2007). In another study, CAD was associated with CD28-CD4+ T cell increase in circulation and correlated positively with IFN $\gamma$ lymphocyte production (Liuzzo et al. 2000). Also, increased amount of CD28-CD4+ cells was an independent predictor of future 
acute coronary events in subjects with unstable angina (Liuzzo et al. 2007).

\section{T cytotoxic lymphocytes}

Tc lymphocytes are generally less abundant than Th lymphocytes in human atherosclerotic plaques; however, they might represent up to $50 \%$ of leukocytes in advanced lesions, where they dominate over Th lymphocytes and contribute to inflammation by TNF $\alpha$ production and to overall plaque instability (Kyaw et al. 2013). Tc lymphocytes promote the development of vulnerable atherosclerotic plaques by activation of macrophage, smooth muscle and endothelial cell apoptosis resulting in necrotic core formation (van der Wal et al. 1989, Kyaw et al. 2013, Paul et al. 2016). Interestingly, however, Tc lymphocytes seem to have both pro-atherogenic and atheroprotective roles, as their cytotoxic activity toward vascular smooth muscle and endothelial cells together with cytokine production drives the progression and instability of the lesions, while cytotoxic activity toward antigen-presenting cells in turn limits atherosclerosis (Saigusa et al. 2020). In contrast, a cardioprotective Tc cell population characterized by the presence of angiotensin type 2 receptor (AT2R) was identified in rat models. This population increases during ischemic heart injury and contributes to maintaining cardiomyocyte viability and IL10 production, hence suggesting the existence of an AT2R-mediated cellular mechanism involved in modulating the adaptive immune response in the heart (Curato et al. 2010).

\section{B lymphocytes}

Experiments with PVAT in mice showed B-1 cells attenuating and B-2 cells aggravating atherosclerosis. B-1 cells limit atherosclerosis development by producing IgM aimed at oxidation of specific epitopes on LDL particles thus blocking oxidized LDL-induced inflammatory cytokine production and foam cell formation (Rosenfeld et al. 2015). As shown by murine transfer studies, B- 2 cells are capable of promoting atherosclerosis development entirely on their own without the need of any other lymphocyte population. In the presence of $\mathrm{T}$ cells or other lymphocytes, they significantly augment atherosclerosis, while their depletion markedly ameliorates plaque formation (Kyaw et al. 2010). Interestingly, B cells predominate in EAT compared to SAT in human subjects regardless of the presence of CAD, although the role of B-1 and B-2 subtypes in the development of coronary atherosclerosis in humans still needs to be addressed (Mraz et al. 2019b).
Besides, the percentage of arterial obstruction increases with the density of B lymphocytes in the periplaque AT, and the density of B cells in the periplaque AT is greater compared with more distant PVAT (Farias-Itao et al. 2019).

\section{Natural killer cells}

Subjects with severe atherosclerosis were shown to have increased amount of circulating NK cells and enhanced the presence of several antigens triggering cytotoxicity and cytokine secretion (e.g. CD160) (Clerc \& Rouz 1997, Zuo et al. 2015). Moreover, NK cells were found directly in atherosclerotic plaques (Bobryshev \& Lord 2005). However, in other studies, CAD was associated with decreased NK cell levels in blood (Backteman et al. 2014) and in EAT compared to SAT (Mraz et al. 2019b), thus their exact role in the development of atherosclerotic complications requires further elucidation.

\section{Natural killer T cells}

As suggested by murine studies (Li et al. 2015) and somehow surprisingly given their anti-inflammatory effects in adipose tissue, NKT cells potently promote atherosclerosis by Prf and granzyme B-dependent apoptosis that increases necrosis and inflammation in atherosclerotic plaques without altering cytokine production. iNKT cell activation during the development of atherosclerosis is at least in part dependent on lipid antigens activating $\mathrm{T}$ cell receptors (TCRs) as shown in mice treated by NK cell CD1ddependent lipid antagonist (Li et al. 2016). Mice lacking both invariant and diverse NKT cells showed increased atherosclerotic lesion area compared to mice lacking only iNKT cell suggesting a possible role of dNKT cells in CAD (Subramanian et al. 2018).

\section{$\gamma \delta$-T cells}

The potential role of $\gamma \delta$-T cells in the development of atherosclerosis and cardiovascular diseases is currently rather unclear as the available data are scarce (Saigusa et al. 2020). $\gamma \delta$-T cells were found in atherosclerotic lesions in both mice and humans (Kleindienst et al. 1993, Vu et al. 2014). However, $\gamma \delta$-T cell-deficient $A p o e^{-/-}$mice developed atherosclerosis as early as their littermates with preserved $\gamma \delta$-T cells (Cheng et al. 2014). Interestingly, the activation and proliferation of $\gamma \delta$-T cells is regulated by their intracellular cholesterol content indicating that increased cholesterol content contributes to their hyperactivated phenotype potentially leading to IL17 production and possibly worsening atherosclerosis (Cheng et al. 2013).
(C) 2021 Society for Endocrinology Published by Bioscientifica Ltd.
Printed in Great Britain 


\section{Dendritic cells}

The presence of chronic CAD did not correlate with total DC content in human EAT (Mraz et al. 2019a). In contrast, in an animal model of acute coronary syndrome, acute ligation of coronary arteries increased the amount of DCs in EAT due to their migration from the infarct site in the myocardium (Horckmans et al. 2018); however, whether this might be a protective or rather a deleterious mechanism remains to be seen.

\section{Conclusion}

Immune cells represent an indispensable part of AT. Through their activities (phagocytosis, direct cell contacts, etc.) and cytokine production, they directly and indirectly influence adipocytes and thus also the metabolic and endocrine function of AT that further affects the homeostasis of the whole organism. AT immune cells of both lean and obese subjects include a variety of immune cells (albeit in different proportions), which reciprocally communicate, affect and complement themselves. In obese subjects, the amount of most immune cells in AT increases, and their phenotype changes toward proinflammatory state. These changes negatively influence adipocyte function, insulin sensitivity and lipid metabolism and create the basis for the development of T2DM, atherosclerosis and subsequent cardiovascular complications.

Cutting-edge research approaches such as single-cell RNA sequencing enable us to take the characterization of AT immune cells as well as adipocytes and their progenitors to the next level thus providing a novel and exciting look at the AT and its homeostatic functions. Therapeutic strategies aimed at reducing the amount of immune cells, favoring beneficial cell subtypes or modifying their phenotype back to the anti-inflammatory state typical for the lean AT might represent a novel approach in combating obesity-related diseases that would directly affect one of the main pathophysiological mechanisms responsible for the metabolic complications of excessive adiposity; however, the development of such treatment approaches is still in its beginnings.

\section{Declaration of interest}

Martin Haluzik is an Editor in Chief of Journal of Endocrinology and Journal of Molecular Endocrinology. Martin Haluzik was not involved in the review or editorial process for this article, on which he is listed as an author. The other authors have nothing to disclose.

\section{Funding}

This work was supported by the grants AZV NU20-02-00190, AZV NV19-0200118 and RVO-VFN64165, and by MH CZ - DRO (Institute for Clinical and Experimental Medicine - IKEM, IN 00023001).

\section{References}

Aamir K, Khan HU, Sethi G, Hossain MA \& Arya A 2020 Wnt signaling mediates TLR pathway and promote unrestrained adipogenesis and metaflammation: therapeutic targets for obesity and type 2 diabetes. Pharmacological Research 152 104602. (https://doi.org/10.1016/j. phrs.2019.104602)

Aron-Wisnewsky J, Tordjman J, Poitou C, Darakhshan F, Hugol D, Basdevant A, Aissat A, Guerre-Millo M \& Clement K 2009 Human adipose tissue macrophages: $\mathrm{m} 1$ and $\mathrm{m} 2$ cell surface markers in subcutaneous and omental depots and after weight loss. Journal of Clinical Endocrinology and Metabolism 94 4619-4623. (https://doi. org/10.1210/jc.2009-0925)

Athie-Morales V, Smits HH, Cantrell DA \& Hilkens CM 2004 Sustained IL-12 signaling is required for Th1 development. Journal of Immunology 172 61-69. (https://doi.org/10.4049/jimmunol.172.1.61)

Backteman K, Ernerudh J \& Jonasson L 2014 Natural killer (NK) cell deficit in coronary artery disease: no aberrations in phenotype but sustained reduction of NK cells is associated with low-grade inflammation. Clinical and Experimental Immunology 175 104-112. (https://doi. org/10.1111/cei.12210)

Baker DJ, Wijshake T, Tchkonia T, LeBrasseur NK, Childs BG, van de Sluis B, Kirkland JL \& van Deursen JM 2011 Clearance of p16Ink4a-positive senescent cells delays ageing-associated disorders. Nature 479 232-236. (https://doi.org/10.1038/nature10600)

Bansal SS, Ismahil MA, Goel M, Patel B, Hamid T, Rokosh G \& Prabhu SD 2017 Activated T lymphocytes are essential drivers of pathological remodeling in ischemic heart failure. Circulation: Heart Failure $\mathbf{1 0}$ e003688. (https://doi.org/10.1161/CIRCHEARTFAILURE.116.003688)

Belge KU, Dayyani F, Horelt A, Siedlar M, Frankenberger M, Frankenberger B, Espevik T \& Ziegler-Heitbrock L 2002 The proinflammatory CD14+CD16+DR++ monocytes are a major source of TNF. Journal of Immunology 168 3536-3542. (https://doi.org/10.4049/ jimmunol.168.7.3536)

Berger A 2000 Th1 and Th2 responses: what are they? BMJ 321424. (https://doi.org/10.1136/bmj.321.7258.424)

Bertola A, Ciucci T, Rousseau D, Bourlier V, Duffaut C, Bonnafous S, BlinWakkach C, Anty R, Iannelli A, Gugenheim J, et al. 2012 Identification of adipose tissue dendritic cells correlated with obesity-associated insulin-resistance and inducing Th17 responses in mice and patients. Diabetes 61 2238-2247. (https://doi.org/10.2337/db11-1274)

Blumenthal A, Ehlers S, Lauber J, Buer J, Lange C, Goldmann T, Heine H, Brandt E \& Reiling N 2006 The wingless homolog WNT5A and its receptor frizzled-5 regulate inflammatory responses of human mononuclear cells induced by microbial stimulation. Blood 108 965-973. (https://doi.org/10.1182/blood-2005-12-5046)

Bobryshev YV \& Lord RS 2005 Identification of natural killer cells in human atherosclerotic plaque. Atherosclerosis 180 423-427. (https:// doi.org/10.1016/j.atherosclerosis.2005.01.046)

Bolus WR, Gutierrez D, Anderson-Baucum E, Kennedy A \& Hasty A 2017 The role of eosinophils in adipose tissue inflammation and metabolic function. Journal of Immunology 198 63.18-63.18.

Born WK, Reardon CL \& O'Brien RL 2006 The function of gammadelta T cells in innate immunity. Current Opinion in Immunology 18 31-38. (https://doi.org/10.1016/j.coi.2005.11.007)

Bourlier V, Zakaroff-Girard A, Miranville A, De Barros S, Maumus M, Sengenes C, Galitzky J, Lafontan M, Karpe F, Frayn KN, et al. 2008 Remodeling phenotype of human subcutaneous adipose tissue 
macrophages. Circulation 117 806-815. (https://doi.org/10.1161/ CIRCULATIONAHA.107.724096)

Caspar-Bauguil S, Cousin B, Galinier A, Segafredo C, Nibbelink M, Andre M, Casteilla L \& Penicaud L 2005 Adipose tissues as an ancestral immune organ: site-specific change in obesity. FEBS Letters $\mathbf{5 7 9}$ 3487-3492. (https://doi.org/10.1016/j.febslet.2005.05.031)

Castro A, Concha LE \& Pantoja C2017 Low-grade inflammation and its relation to obesity and chronic degenerative diseases . Revista Médica del Hospital General de México 80101 - 105 . (https://doi.org/10.1016/j. hgmx.2016.06.011)

Catalan V, Gomez-Ambrosi J, Rodriguez A, Perez-Hernandez AI, Gurbindo J, Ramirez B, Mendez-Gimenez L, Rotellar F, Valenti V, Moncada R, et al. 2014 Activation of noncanonical Wnt signaling through WNT5A in visceral adipose tissue of obese subjects is related to inflammation. Journal of Clinical Endocrinology and Metabolism 99 E1407-E1417. (https://doi.org/10.1210/jc.2014-1191)

Charriere G, Cousin B, Arnaud E, Andre M, Bacou F, Penicaud L \& Casteilla L 2003 Preadipocyte conversion to macrophage. Evidence of plasticity. Journal of Biological Chemistry 278 9850-9855. (https://doi. org/10.1074/jbc.M210811200)

Chaudhry A, Samstein RM, Treuting P, Liang Y, Pils MC, Heinrich JM, Jack RS, Wunderlich FT, Bruning JC, Muller W, et al. 2011 Interleukin-10 signaling in regulatory $\mathrm{T}$ cells is required for suppression of Th17 cell-mediated inflammation. Immunity 34 566-578. (https://doi. org/10.1016/j.immuni.2011.03.018)

Chen Y, Tian J, Tian X, Tang X, Rui K, Tong J, Lu L, Xu H \& Wang S 2014 Adipose tissue dendritic cells enhances inflammation by prompting the generation of Th17 cells. PLOS ONE 9 e92450. (https://doi. org/10.1371/journal.pone.0092450)

Cheng KH, Chu CS, Lee KT, Lin TH, Hsieh CC, Chiu CC, Voon WC, Sheu SH \& Lai WT 2008 Adipocytokines and proinflammatory mediators from abdominal and epicardial adipose tissue in patients with coronary artery disease. International Journal of Obesity $\mathbf{3 2}$ 268-274. (https://doi.org/10.1038/sj.ijo.0803726)

Cheng HY, Wu R, Gebre AK, Hanna RN, Smith DJ, Parks JS, Ley K \& Hedrick CC 2013 Increased cholesterol content in gammadelta (gammadelta) T lymphocytes differentially regulates their activation. PLOS ONE 8 e63746. (https://doi.org/10.1371/journal.pone.0063746)

Cheng HY, Wu R \& Hedrick CC 2014 Gammadelta (gammadelta) T lymphocytes do not impact the development of early atherosclerosis. Atherosclerosis 234 265-269. (https://doi.org/10.1016/j. atherosclerosis.2014.03.007)

Cho KW, Zamarron BF, Muir LA, Singer K, Porsche CE, DelProposto JB, Geletka L, Meyer KA, O'Rourke RW \& Lumeng CN 2016 Adipose tissue dendritic cells are independent contributors to obesity-induced inflammation and insulin resistance. Journal of Immunology 197 3650-3661. (https://doi.org/10.4049/jimmunol.1600820)

Cinkajzlova A, Mraz M \& Haluzik M 2017 a Lymphocytes and macrophages in adipose tissue in obesity: markers or makers of subclinical inflammation? Protoplasma 254 1219-1232. (https://doi.org/10.1007/ s00709-017-1082-3)

Cinkajzlova A, Lacinova Z, Klouckova J, Kavalkova P, Trachta P, Kosak M, Kratky J, Kasalicky M, DoleZalova K, Mraz M, et al. 2017 b An alternatively activated macrophage marker CD163 in severely obese patients: the influence of very low-calorie diet and bariatric surgery. Physiological Research 66 641-652. (https://doi.org/10.33549/ physiolres.933522)

Cinkajzlova A, Anderlova K, Simjak P, Lacinova Z, Klouckova J, Kratochvilova H, Krejci H, Parizek A, Mraz M, Krsek M, et al. 2020 Subclinical inflammation and adipose tissue lymphocytes in pregnant females with gestational diabetes mellitus. Journal of Clinical Endocrinology and Metabolism 105 dgaa528. (https://doi.org/10.1210/ clinem/dgaa528)

Clerc G \& Rouz PM 1997 Lymphocyte subsets in severe atherosclerosis before revascularization. Annals of Internal Medicine 126 1004-1005. (https://doi.org/10.7326/0003-4819-126-12-199706150-00028)
Coats BR, Schoenfelt KQ, Barbosa-Lorenzi VC, Peris E, Cui C, Hoffman A, Zhou G, Fernandez S, Zhai L, Hall BA, et al. 2017 Metabolically activated adipose tissue macrophages perform detrimental and beneficial functions during diet-induced obesity. Cell Reports 20 3149-3161. (https://doi.org/10.1016/j.celrep.2017.08.096)

Coppe JP, Patil CK, Rodier F, Sun Y, Munoz DP, Goldstein J, Nelson PS, Desprez PY \& Campisi J 2008 Senescence-associated secretory phenotypes reveal cell-nonautonomous functions of oncogenic RAS and the p53 tumor suppressor. PLoS Biology 6 2853-2868. (https://doi. org/10.1371/journal.pbio.0060301)

Cousin B, Munoz O, Andre M, Fontanilles AM, Dani C, Cousin JL, Laharrague P, Casteilla L \& Penicaud L 1999 A role for preadipocytes as macrophage-like cells. FASEB Journal 13 305-312. (https://doi. $\operatorname{org} / 10.1096 /$ fasebj.13.2.305)

Cousin B, Andre M, Casteilla L \& Penicaud L 2001 Altered macrophage-like functions of preadipocytes in inflammation and genetic obesity. Journal of Cellular Physiology 186 380-386. (https://doi.org/10.1002/10974652(2001)9999:9999<000::AID-JCP1038>3.0.CO;2-T)

Curato C, Slavic S, Dong J, Skorska A, Altarche-Xifro W, Miteva K, Kaschina E, Thiel A, Imboden H, Wang J, et al. 2010 Identification of noncytotoxic and IL-10-producing CD8+AT2R+ T cell population in response to ischemic heart injury. Journal of Immunology 185 6286-6293. (https://doi.org/10.4049/jimmunol.0903681)

de Vos AM, Prokop M, Roos CJ, Meijs MF, van der Schouw YT, Rutten A, Gorter PM, Cramer MJ, Doevendans PA, Rensing BJ, et al. 2008 Pericoronary epicardial adipose tissue is related to cardiovascular risk factors and coronary artery calcification in post-menopausal women. European Heart Journal 29 777-783. (https://doi.org/10.1093/eurheartj/ ehm564)

Deauvieau F, Ollion V, Doffin AC, Achard C, Fonteneau JF, Verronese E, Durand I, Ghittoni R, Marvel J, Dezutter-Dambuyant C, et al. 2015 Human natural killer cells promote cross-presentation of tumor cellderived antigens by dendritic cells. International Journal of Cancer 136 1085-1094. (https://doi.org/10.1002/ijc.29087)

DeFuria J, Belkina AC, Jagannathan-Bogdan M, Snyder-Cappione J, Carr JD, Nersesova YR, Markham D, Strissel KJ, Watkins AA, Zhu M, et al. 2013 $B$ cells promote inflammation in obesity and type 2 diabetes through regulation of T-cell function and an inflammatory cytokine profile. PNAS 110 5133-5138. (https://doi.org/10.1073/pnas.1215840110)

Dobrzanski MJ, Reome JB, Hollenbaugh JA \& Dutton RW 2004 Tc1 and Tc2 effector cell therapy elicit long-term tumor immunity by contrasting mechanisms that result in complementary endogenous type 1 antitumor responses. Journal of Immunology 172 1380-1390. (https:// doi.org/10.4049/jimmunol.172.3.1380)

Eberl M, Roberts GW, Meuter S, Williams JD, Topley N \& Moser B 2009 A rapid crosstalk of human gammadelta $T$ cells and monocytes drives the acute inflammation in bacterial infections. PLoS Pathogens 5 e1000308. (https://doi.org/10.1371/journal.ppat.1000308)

Echouffo-Tcheugui JB, Short MI, Xanthakis V, Field P, Sponholtz TR, Larson MG \& Vasan RS 2019 Natural history of obesity subphenotypes: dynamic changes over two decades and prognosis in the Framingham heart study. Journal of Clinical Endocrinology and Metabolism 104 738-752. (https://doi.org/10.1210/jc.2018-01321)

Eid RE, Rao DA, Zhou J, Lo SF, Ranjbaran H, Gallo A, Sokol SI, Pfau S, Pober JS \& Tellides G 2009 Interleukin-17 and interferon-gamma are produced concomitantly by human coronary artery-infiltrating T cells and act synergistically on vascular smooth muscle cells. Circulation 119 1424-1432. (https://doi.org/10.1161/CIRCULATIONAHA.108.827618)

Elgazar-Carmon V, Rudich A, Hadad N \& Levy R 2008 Neutrophils transiently infiltrate intra-abdominal fat early in the course of high-fat feeding. Journal of Lipid Research 49 1894-1903. (https://doi. org/10.1194/jlr.M800132-JLR200)

Elgueta R, Benson MJ, de Vries VC, Wasiuk A, Guo Y \& Noelle RJ 2009 Molecular mechanism and function of CD40/CD40L engagement in the immune system. Immunological Reviews 229 152-172. (https://doi. org/10.1111/j.1600-065X.2009.00782.x) https://joe.bioscientifica.com

https://doi.org/10.1530/JOE-21-0159 (c) 2021 Society for Endocrinology Published by Bioscientifica Ltd. Printed in Great Britain 
Engelbertsen D, Andersson L, Ljungcrantz I, Wigren M, Hedblad B, Nilsson J \& Bjorkbacka H 2013 T-helper 2 immunity is associated with reduced risk of myocardial infarction and stroke. Arteriosclerosis, Thrombosis, and Vascular Biology 33 637-644. (https://doi.org/10.1161/ ATVBAHA.112.300871)

Erbel C, Dengler TJ, Wangler S, Lasitschka F, Bea F, Wambsganss N, Hakimi M, Bockler D, Katus HA \& Gleissner CA 2011 Expression of IL-17A in human atherosclerotic lesions is associated with increased inflammation and plaque vulnerability. Basic Research in Cardiology 106 125-134. (https://doi.org/10.1007/s00395-010-0135-y)

Farias-Itao DS, Pasqualucci CA, Nishizawa A, Silva LFFd, Campos FM, Bittencourt MS, Silva KCSd, Leite REP, Grinberg LT, FerrettiRebustini REdL, et al. 2019 B lymphocytes and macrophages in the perivascular adipose tissue are associated with coronary atherosclerosis: an autopsy study. Journal of the American Heart Association 8 e013793.(https://doi.org/10.1161/JAHA.119.013793)

Farmer SR 2005 Regulation of PPARgamma activity during adipogenesis. International Journal of Obesity 29 (Supplement 1) S13-S16. (https://doi. org/10.1038/sj.ijo.0802907)

Fernandez DM, Rahman AH, Fernandez NF, Chudnovskiy A, Amir ED, Amadori L, Khan NS, Wong CK, Shamailova R, Hill CA, et al. 2019 Single-cell immune landscape of human atherosclerotic plaques. Nature Medicine 25 1576-1588. (https://doi.org/10.1038/s41591-0190590-4)

Ferrari R 1999 The role of TNF in cardiovascular disease. Pharmacological Research 40 97-105. (https://doi.org/10.1006/phrs.1998.0463)

Feuerer M, Herrero L, Cipolletta D, Naaz A, Wong J, Nayer A, Lee J, Goldfine AB, Benoist C, Shoelson S, et al. 2009 Lean, but not obese, fat is enriched for a unique population of regulatory $\mathrm{T}$ cells that affect metabolic parameters. Nature Medicine 15 930-939. (https://doi. org/10.1038/nm.2002)

Freeman BE, Hammarlund E, Raue HP \& Slifka MK 2012 Regulation of innate CD8+ T-cell activation mediated by cytokines. PNAS 109 9971-9976. (https://doi.org/10.1073/pnas.1203543109)

Fujisaka S, Usui I, Kanatani Y, Ikutani M, Takasaki I, Tsuneyama K, Tabuchi Y, Bukhari A, Yamazaki Y, Suzuki H, et al. 2011 Telmisartan improves insulin resistance and modulates adipose tissue macrophage polarization in high-fat-fed mice. Endocrinology 152 1789-1799. (https://doi.org/10.1210/en.2010-1312)

Fuster JJ, Zuriaga MA, Ngo DT, Farb MG, Aprahamian T, Yamaguchi TP, Gokce N \& Walsh K 2015 Noncanonical Wnt signaling promotes obesity-induced adipose tissue inflammation and metabolic dysfunction independent of adipose tissue expansion. Diabetes 64 1235-1248. (https://doi.org/10.2337/db14-1164)

Gao S, Deng Y, Wu J, Zhang L, Deng F, Zhou J, Yuan Z \& Wang L 2019 Eosinophils count in peripheral circulation is associated with coronary artery disease. Atherosclerosis 286 128-134. (https://doi.org/10.1016/j. atherosclerosis.2019.05.027)

Garcia-Hernandez MH, Rodriguez-Varela E, Garcia-Jacobo RE, Hernandez-De la Torre M, Uresti-Rivera EE, Gonzalez-Amaro R \& Portales-Perez DP 2018 Frequency of regulatory B cells in adipose tissue and peripheral blood from individuals with overweight, obesity and normal-weight. Obesity Research and Clinical Practice 12 513-519. (https://doi.org/10.1016/j.orcp.2018.07.001)

Garcia-Rubio J, Leon J, Redruello-Romero A, Pavon E, Cozar A, Tamayo F, Caba-Molina M, Salmeron J \& Carazo Á 2018 Cytometric analysis of adipose tissue reveals increments of adipocyte progenitor cells after weight loss induced by bariatric surgery. Scientific Reports 815203. (https://doi.org/10.1038/s41598-018-33488-7)

Geering B, Stoeckle C, Conus S \& Simon HU 2013 Living and dying for inflammation: neutrophils, eosinophils, basophils. Trends in Immunology 34 398-409. (https://doi.org/10.1016/j.it.2013.04.002)

Ghosh AK, Mau T, O’Brien M, Garg S \& Yung R 2016 Impaired autophagy activity is linked to elevated ER-stress and inflammation in aging adipose tissue. Aging 8 2525-2537. (https://doi.org/10.18632/ aging.101083)
Gilliet M, Cao W \& Liu YJ 2008 Plasmacytoid dendritic cells: sensing nucleic acids in viral infection and autoimmune diseases. Nature Reviews: Immunology 8 594-606. (https://doi.org/10.1038/nri2358)

Goldberg EL, Shchukina I, Asher JL, Sidorov S, Artyomov MN \& Dixit VD 2020 Ketogenesis activates metabolically protective gammadelta T cells in visceral adipose tissue. Nature Metabolism 2 50-61. (https://doi. org/10.1038/s42255-019-0160-6)

Gordon S 2003 Alternative activation of macrophages. Nature Reviews: Immunology 3 23-35. (https://doi.org/10.1038/nri978)

Gordon S \& Taylor PR 2005 Monocyte and macrophage heterogeneity. Nature Reviews: Immunology 5 953-964. (https://doi.org/10.1038/nri1733)

Gunasekar P, Swier VJ, Fleegel JP, Boosani CS, Radwan MM \& Agrawal DK 2018 Vitamin D and macrophage polarization in epicardial adipose tissue of atherosclerotic swine. PLOS ONE 13 e0199411. (https://doi. org/10.1371/journal.pone.0199411)

Guzzardi MA \& Iozzo P 2011 Fatty heart, cardiac damage, and inflammation. Review of Diabetic Studies 8 403-417. (https://doi. org/10.1900/RDS.2011.8.403)

Hams E, Locksley RM, McKenzie AN \& Fallon PG 2013 Cutting edge: il-25 elicits innate lymphoid type 2 and type II NKT cells that regulate obesity in mice. Journal of Immunology 191 5349-5353. (https://doi. org/10.4049/jimmunol.1301176)

Han SF, Liu P, Zhang W, Bu L, Shen M, Li H, Fan YH, Cheng K, Cheng HX, Li CX, et al. 2007 The opposite-direction modulation of CD4+CD25+ Tregs and Thelper 1 cells in acute coronary syndromes. Clinical Immunology 124 90-97. (https://doi.org/10.1016/j.clim.2007.03.546)

Harmon DB, Srikakulapu P, Kaplan JL, Oldham SN, McSkimming C, Garmey JC, Perry HM, Kirby JL, Prohaska TA, Gonen A, et al. 2016 Protective role for B-1b B cells and IgM in obesity-associated inflammation, glucose intolerance, and insulin resistance. Arteriosclerosis, Thrombosis, and Vascular Biology 36 682-691. (https:// doi.org/10.1161/ATVBAHA.116.307166)

Hashimoto D, Chow A, Noizat C, Teo P, Beasley MB, Leboeuf M, Becker CD, See P, Price J, Lucas D, et al. 2013 Tissue-resident macrophages selfmaintain locally throughout adult life with minimal contribution from circulating monocytes. Immunity 38 792-804. (https://doi. org/10.1016/j.immuni.2013.04.004)

He SH, Zhang HY, Zeng XN, Chen D \& Yang PC 2013 Mast cells and basophils are essential for allergies: mechanisms of allergic inflammation and a proposed procedure for diagnosis. Acta Pharmacologica Sinica 34 1270-1283. (https://doi.org/10.1038/ aps.2013.88)

Henrichot E, Juge-Aubry CE, Pernin A, Pache JC, Velebit V, Dayer JM, Meda P, Chizzolini C \& Meier CA 2005 Production of chemokines by perivascular adipose tissue: a role in the pathogenesis of atherosclerosis? Arteriosclerosis, Thrombosis, and Vascular Biology 25 2594-2599. (https://doi.org/10.1161/01.ATV.0000188508.40052.35)

Henry CJ, Ornelles DA, Mitchell LM, Brzoza-Lewis KL \& Hiltbold EM 2008 IL-12 produced by dendritic cells augments CD8+ T cell activation through the production of the chemokines CCL1 and CCL17. Journal of Immunology 181 8576-8584. (https://doi.org/10.4049/ jimmunol.181.12.8576)

Hildreth AD, Ma F, Wong YY, Sun R, Pellegrini M \& O'Sullivan TE 2021 Single-cell sequencing of human white adipose tissue identifies new cell states in health and obesity. Nature Immunology 22 639-653. (https://doi.org/10.1038/s41590-021-00922-4)

Hirata Y, Tabata M, Kurobe H, Motoki T, Akaike M, Nishio C, Higashida M, Mikasa H, Nakaya Y, Takanashi S, et al. 2011 Coronary atherosclerosis is associated with macrophage polarization in epicardial adipose tissue. Journal of the American College of Cardiology 58 248-255. (https://doi. $\operatorname{org} / 10.1016 / j . j a c c .2011 .01 .048)$

Horckmans M, Bianchini M, Santovito D, Megens RTA, Springael JY, Negri I, Vacca M, Di Eusanio M, Moschetta A, Weber C, et al. 2018 Pericardial adipose tissue regulates granulopoiesis, fibrosis, and cardiac function after myocardial infarction. Circulation 137 948-960. (https:// doi.org/10.1161/CIRCULATIONAHA.117.028833) 
Hu B, Jin C, Zeng X, Resch JM, Jedrychowski MP, Yang Z, Desai BN, Banks AS, Lowell BB, Mathis D, et al. 20202020 gammadelta T cells and adipocyte IL-17RC control fat innervation and thermogenesis. Nature 578 610-614. (https://doi.org/10.1038/s41586-020-2028-z)

Huda SS, Jordan F, Bray J, Love G, Payne R, Sattar N \& Freeman DJ 2017 Visceral adipose tissue activated macrophage content and inflammatory adipokine secretion is higher in pre-eclampsia than in healthy pregnancys. Clinical Science 131 1529-1540. (https://doi. org/10.1042/CS20160832)

Huh JY, Park J, Kim JI, Park YJ, Lee YK \& Kim JB 2017 Deletion of CD1d in adipocytes aggravates adipose tissue inflammation and insulin resistance in obesity. Diabetes 66 835-847. (https://doi.org/10.2337/ db16-1122)

Ibrahim MM 2010 Subcutaneous and visceral adipose tissue: structural and functional differences. Obesity Reviews 11 11-18. (https://doi. org/10.1111/j.1467-789X.2009.00623.x)

Ionita MG, van den Borne P, Catanzariti LM, Moll FL, de Vries JP, Pasterkamp G, Vink A \& de Kleijn DP 2010 High neutrophil numbers in human carotid atherosclerotic plaques are associated with characteristics of rupture-prone lesions. Arteriosclerosis, Thrombosis, and Vascular Biology 30 1842-1848. (https://doi.org/10.1161/ ATVBAHA.110.209296)

Iwakura Y \& Ishigame H 2006 The IL-23/IL-17 axis in inflammation. Journal of Clinical Investigation 116 1218-1222. (https://doi.org/10.1172/ JCI28508)

Jacobsen EA, Helmers RA, Lee JJ \& Lee NA 2012 The expanding role(s) of eosinophils in health and disease. Blood 120 3882-3890. (https://doi. org/10.1182/blood-2012-06-330845)

Jaitin DA, Adlung L, Thaiss CA, Weiner A, Li B, Descamps H, Lundgren P, Bleriot C, Liu Z, Deczkowska A, et al. 2019 Lipid-associated macrophages control metabolic homeostasis in a Trem2-dependent manner. Cell 178 686.e14-698.e14. (https://doi.org/10.1016/j. cell.2019.05.054)

Jiang E, Perrard XD, Yang D, Khan IM, Perrard JL, Smith CW, Ballantyne CM \& Wu H 2014 Essential role of CD11a in CD8+ T-cell accumulation and activation in adipose tissue. Arteriosclerosis, Thrombosis, and Vascular Biology 34 34-43. (https://doi.org/10.1161/ ATVBAHA.113.302077)

Joller N, Lozano E, Burkett PR, Patel B, Xiao S, Zhu C, Xia J, Tan TG, Sefik E, Yajnik V, et al. 2014 Treg cells expressing the coinhibitory molecule TIGIT selectively inhibit proinflammatory Th1 and Th17 cell responses. Immunity 40 569-581. (https://doi.org/10.1016/j.immuni.2014.02.012)

Kleindienst R, Xu Q, Willeit J, Waldenberger FR, Weimann S \& Wick G 1993 Immunology of atherosclerosis. Demonstration of heat shock protein 60 expression and $\mathrm{T}$ lymphocytes bearing alpha/beta or gamma/delta receptor in human atherosclerotic lesions. American Journal of Pathology 142 1927-1937.

Koenen TB, Stienstra R, van Tits LJ, Joosten LA, van Velzen JF, Hijmans A, Pol JA, van der Vliet JA, Netea MG, Tack CJ, et al. 2011 The inflammasome and caspase- 1 activation: a new mechanism underlying increased inflammatory activity in human visceral adipose tissue. Endocrinology 152 3769-3778. (https://doi.org/10.1210/en.2010-1480)

Kohlgruber AC, Gal-Oz ST, LaMarche NM, Shimazaki M, Duquette D, Koay HF, Nguyen HN, Mina AI, Paras T, Tavakkoli A, et al. 2018 Г $\mathrm{T}$ cells producing interleukin-17A regulate adipose regulatory $\mathrm{T}$ cell homeostasis and thermogenesis. Nature Immunology 19 464-474. (https://doi.org/10.1038/s41590-018-0094-2)

Kralova Lesna I, Tonar Z, Malek I, Maluskova J, Nedorost L, Pirk J, Pitha J, Lanska V \& Poledne R 2015 Is the amount of coronary perivascular fat related to atherosclerosis? Physiological Research $\mathbf{6 4}$ S435-S443. (https:// doi.org/10.33549/physiolres.933151)

Kratz M, Coats BR, Hisert KB, Hagman D, Mutskov V, Peris E, Schoenfelt KQ, Kuzma JN, Larson I, Billing PS, et al. 2014 Metabolic dysfunction drives a mechanistically distinct proinflammatory phenotype in adipose tissue macrophages. Cell Metabolism 20 614-625. (https://doi.org/10.1016/i.cmet.2014.08.010)
Kritikou E, Kuiper J, Kovanen PT \& Bot I 2016 The impact of mast cells on cardiovascular diseases. European Journal of Pharmacology 778 103-115. (https://doi.org/10.1016/j.ejphar.2015.04.050)

Kumar H, Kawai T \& Akira S 2011 Pathogen recognition by the innate immune system. International Reviews of Immunology 30 16-34. (https:// doi.org/10.3109/08830185.2010.529976)

Kyaw T, Tay C, Khan A, Dumouchel V, Cao A, To K, Kehry M, Dunn R, Agrotis A, Tipping P, et al. 2010 Conventional B2 B cell depletion ameliorates whereas its adoptive transfer aggravates atherosclerosis. Journal of Immunology 185 4410-4419. (https://doi.org/10.4049/ jimmunol.1000033)

Kyaw T, Winship A, Tay C, Kanellakis P, Hosseini H, Cao A, Li P, Tipping P, Bobik A \& Toh BH 2013 Cytotoxic and proinflammatory CD8+ T lymphocytes promote development of vulnerable atherosclerotic plaques in apoE-deficient mice. Circulation 127 1028-1039. (https:// doi.org/10.1161/CIRCULATIONAHA.112.001347)

Le Menn G, Sibille B, Murdaca J, Rousseau AS, Squillace R, Vergoni B, Cormont M, Niot I, Grimaldi PA, Mothe-Satney I, et al. 2019 Decrease in alphabeta/gammadelta T-cell ratio is accompanied by a reduction in high-fat diet-induced weight gain, insulin resistance, and inflammation. FASEB Journal 33 2553-2562. (https://doi.org/10.1096/ fj.201800696RR)

Lee BC, Kim MS, Pae M, Yamamoto Y, Eberle D, Shimada T, Kamei N, Park HS, Sasorith S, Woo JR, et al. 2016 Adipose natural killer cells regulate adipose tissue macrophages to promote insulin resistance in obesity. Cell Metabolism 23 685-698. (https://doi.org/10.1016/j. cmet.2016.03.002)

Lee EH, Itan M, Jang J, Gu HJ, Rozenberg P, Mingler MK, Wen T, Yoon J, Park SY, Roh JY, et al. 2018 Eosinophils support adipocyte maturation and promote glucose tolerance in obesity. Scientific Reports 89894 . (https://doi.org/10.1038/s41598-018-28371-4)

Lee KA, Robbins PD \& Camell CD 2021 Intersection of immunometabolism and immunosenescence during aging. Current Opinion in Pharmacology 57 107-116. (https://doi.org/10.1016/j.coph.2021.01.003)

Leik CE \& Walsh SW 2004 Neutrophils infiltrate resistance-sized vessels of subcutaneous fat in women with preeclampsia. Hypertension 44 72-77. (https://doi.org/10.1161/01.HYP.0000130483.83154.37)

Leslie DS, Vincent MS, Spada FM, Das H, Sugita M, Morita CT \& Brenner MB 2002 CD1-mediated gamma/delta T cell maturation of dendritic cells. Journal of Experimental Medicine 196 1575-1584. (https:// doi.org/10.1084/jem.20021515)

Li P, Lu M, Nguyen MTA, Bae EJ, Chapman J, Feng D, Hawkins M, Pessin JE, Sears DD, Nguyen AK, et al. 2010 Functional heterogeneity of CD11cpositive adipose tissue macrophages in diet-induced obese mice. Journal of Biological Chemistry 285 15333-15345. (https://doi.org/10.1074/jbc. M110.100263)

Li Y, To K, Kanellakis P, Hosseini H, Deswaerte V, Tipping P, Smyth MJ, Toh BH, Bobik A \& Kyaw T 2015 CD4+ natural killer T cells potently augment aortic root atherosclerosis by perforin- and granzyme B-dependent cytotoxicity. Circulation Research 116 245-254. (https:// doi.org/10.1161/CIRCRESAHA.116.304734)

Li Y, Kanellakis P, Hosseini H, Cao A, Deswaerte V, Tipping P, Toh BH, Bobik A \& Kyaw T 2016 A CD1d-dependent lipid antagonist to NKT cells ameliorates atherosclerosis in ApoE-/- mice by reducing lesion necrosis and inflammation. Cardiovascular Research 109 305-317. (https://doi.org/10.1093/cvr/cvv259)

Lin A \& Lore K 2017 Granulocytes: new members of the antigen-presenting cell family. Frontiers in Immunology 8 1781. (https://doi.org/10.3389/ fimmu.2017.01781)

Lin AM, Rubin CJ, Khandpur R, Wang JY, Riblett M, Yalavarthi S, Villanueva EC, Shah P, Kaplan MJ \& Bruce AT 2011 Mast cells and neutrophils release IL-17 through extracellular trap formation in psoriasis. Journal of Immunology 187 490-500. (https://doi.org/10.4049/ jimmunol.1100123)

Lindstedt KA, Kokkonen JO \& Kovanen PT 1992 Soluble heparin proteoglycans released from stimulated mast cells induce uptake of https://joe.bioscientifica.com

https://doi.org/10.1530/JOE-21-0159 (c) 2021 Society for Endocrinology Published by Bioscientifica Ltd. Printed in Great Britain 
low density lipoproteins by macrophages via scavenger receptormediated phagocytosis. Journal of Lipid Research 33 65-75. (https://doi. org/10.1016/S0022-2275(20)41884-X)

Liu J, Divoux A, Sun J, Zhang J, Clement K, Glickman JN, Sukhova GK, Wolters PJ, Du J, Gorgun CZ, et al. 2009 Genetic deficiency and pharmacological stabilization of mast cells reduce diet-induced obesity and diabetes in mice. Nature Medicine 15 940-945. (https://doi. org/10.1038/nm.1994)

Liuzzo G, Kopecky SL, Frye RL, O’Fallon WM, Maseri A, Goronzy JJ \& Weyand CM 1999 Perturbation of the T-cell repertoire in patients with unstable angina. Circulation 100 2135-2139. (https://doi. org/10.1161/01.cir.100.21.2135)

Liuzzo G, Goronzy JJ, Yang H, Kopecky SL, Holmes DR, Frye RL \& Weyand CM 2000 Monoclonal T-cell proliferation and plaque instability in acute coronary syndromes. Circulation $1012883-2888$. (https://doi.org/10.1161/01.cir.101.25.2883)

Liuzzo G, Biasucci LM, Trotta G, Brugaletta S, Pinnelli M, Digianuario G, Rizzello V, Rebuzzi AG, Rumi C, Maseri A, et al. 2007 Unusual CD4+CD28null T lymphocytes and recurrence of acute coronary events. Journal of the American College of Cardiology 50 1450-1458. (https://doi.org/10.1016/j.jacc.2007.06.040)

Lumeng CN, Bodzin JL \& Saltiel AR 2007 Obesity induces a phenotypic switch in adipose tissue macrophage polarization. Journal of Clinical Investigation 117 175-184. (https://doi.org/10.1172/JCI29881)

Lumeng CN, DelProposto JB, Westcott DJ \& Saltiel AR 2008 Phenotypic switching of adipose tissue macrophages with obesity is generated by spatiotemporal differences in macrophage subtypes. Diabetes $\mathbf{5 7}$ 3239-3246. (https://doi.org/10.2337/db08-0872)

Lynch L, O'Shea D, Winter DC, Geoghegan J, Doherty DG \& O'Farrelly C 2009 Invariant NKT cells and CD1d(+) cells amass in human omentum and are depleted in patients with cancer and obesity. European Journal of Immunology 39 1893-1901. (https://doi. org/10.1002/eji.200939349)

Lynch L, Nowak M, Varghese B, Clark J, Hogan AE, Toxavidis V, Balk SP, O'Shea D, O'Farrelly C \& Exley MA 2012 Adipose tissue invariant NKT cells protect against diet-induced obesity and metabolic disorder through regulatory cytokine production. Immunity $\mathbf{3 7} 574-587$. (https://doi.org/10.1016/j.immuni.2012.06.016)

Macdougall CE, Wood EG, Loschko J, Scagliotti V, Cassidy FC, Robinson ME, Feldhahn N, Castellano L, Voisin MB, Marelli-Berg F, et al. 2018 Visceral adipose tissue immune homeostasis is regulated by the crosstalk between adipocytes and dendritic cell subsets. Cell Metabolism 27 588.e4-601.e4. (https://doi.org/10.1016/j.cmet.2018.02.007)

Magalang UJ, Rajappan R, Hunter MG, Kutala VK, Kuppusamy P, Wewers MD, Marsh CB \& Parinandi NL 2006 Adiponectin inhibits superoxide generation by human neutrophils. Antioxidants and Redox Signaling 8 2179-2186. (https://doi.org/10.1089/ars.2006.8.2179)

Mahajan VS, Mattoo H, Sun N, Viswanadham V, Yuen GJ, AllardChamard H, Ahmad M, Murphy SJ, Cariappa A, Tuncay Y, et al. 2021 B1 and B2 B cells are characterized by distinct CpG modification states at DNMT3A-maintained enhancers. Nature Communications 12,2208.(https://doi.org/10.1038/s41467-021-22458-9)

Mancuso P \& Bouchard B 2019 The impact of aging on adipose function and adipokine synthesis. Frontiers in Endocrinology 10 137. (https://doi. org/10.3389/fendo.2019.00137)

Maniar A, Zhang X, Lin W, Gastman BR, Pauza CD, Strome SE \& Chapoval AI 2010 Human gammadelta T lymphocytes induce robust NK cell-mediated antitumor cytotoxicity through CD137 engagement. Blood 116 1726-1733. (https://doi.org/10.1182/blood-2009-07-234211)

Mantovani A, Sica A, Sozzani S, Allavena P, Vecchi A \& Locati M 2004 The chemokine system in diverse forms of macrophage activation and polarization. Trends in Immunology 25 677-686. (https://doi. org/10.1016/j.it.2004.09.015)

Marone G, Casolaro V, Patella V, Florio G \& Triggiani M 1997 Molecular and cellular biology of mast cells and basophils. International
Archives of Allergy and Immunology 114 207-217. (https://doi. org/10.1159/000237670)

Martinez FO \& Gordon S 2014 The M1 and M2 paradigm of macrophage activation: time for reassessment. F1000prime Reports 6 13. (https://doi. org/10.12703/P6-13)

Martin-Fontecha A, Thomsen LL, Brett S, Gerard C, Lipp M, Lanzavecchia A \& Sallusto F 2004 Induced recruitment of NK cells to lymph nodes provides IFN-gamma for $\mathrm{T}(\mathrm{H}) 1$ priming. Nature Immunology $\mathbf{5}$ 1260-1265. (https://doi.org/10.1038/ni1138)

McDonnell ME, Ganley-Leal LM, Mehta A, Bigornia SJ, Mott M, Rehman Q, Farb MG, Hess DT, Joseph L, Gokce N, et al. 2012 B lymphocytes in human subcutaneous adipose crown-like structures. Obesity 20 1372-1378. (https://doi.org/10.1038/oby.2012.54)

McLaughlin T, Liu LF, Lamendola C, Shen L, Morton J, Rivas H, Winer D, Tolentino L, Choi O, Zhang H, et al. 2014 T-cell profile in adipose tissue is associated with insulin resistance and systemic inflammation in humans. Arteriosclerosis, Thrombosis, and Vascular Biology 34 2637-2643. (https://doi.org/10.1161/ATVBAHA.114.304636)

Mehta P, Nuotio-Antar AM \& Smith CW 2015 Gammadelta T cells promote inflammation and insulin resistance during high fat diet-induced obesity in mice. Journal of Leukocyte Biology 97 121-134. (https://doi. org/10.1189/jlb.3A0414-211RR)

Methe H, Brunner S, Wiegand D, Nabauer M, Koglin J \& Edelman ER 2005 Enhanced T-helper-1 lymphocyte activation patterns in acute coronary syndromes. Journal of the American College of Cardiology 45 1939-1945. (https://doi.org/10.1016/j.jacc.2005.03.040)

Metkar SS, Menaa C, Pardo J, Wang B, Wallich R, Freudenberg M, Kim S, Raja SM, Shi L, Simon MM, et al. 2008 Human and mouse granzyme A induce a proinflammatory cytokine response. Immunity 29 720-733. (https://doi.org/10.1016/j.immuni.2008.08.014)

Mills CD, Kincaid K, Alt JM, Heilman MJ \& Hill AM 2000 M-1/M-2 macrophages and the Th1/Th2 paradigm. Journal of Immunology 164 6166-6173. (https://doi.org/10.4049/jimmunol.164.12.6166)

Min SY, Desai A, Yang Z, Sharma A, DeSouza T, Genga RMJ, Kucukural A, Lifshitz LM, Nielsen S, Scheele C, et al. 2019 Diverse repertoire of human adipocyte subtypes develops from transcriptionally distinct mesenchymal progenitor cells. PNAS 116 17970-17979. (https://doi org/10.1073/pnas.1906512116)

Minns D, Smith KJ \& Findlay EG 2019 Orchestration of adaptive T cell responses by neutrophil granule contents. Mediators of Inflammation 2019 8968943. (https://doi.org/10.1155/2019/8968943)

Mosig S, Rennert K, Krause S, Kzhyshkowska J, Neunubel K, Heller R \& Funke H 2009 Different functions of monocyte subsets in familial hypercholesterolemia: potential function of CD14+ CD16+ monocytes in detoxification of oxidized LDL. FASEB Journal 23 866-874. (https:// doi.org/10.1096/fj.08-118240)

Moysidou M, Karaliota S, Kodela E, Salagianni M, Koutmani Y, Katsouda A, Kodella K, Tsakanikas P, Ourailidou S, Andreakos E, et al. 2018 CD8+ $\mathrm{T}$ cells in beige adipogenesis and energy homeostasis. JCI Insight 3 e95456. (https://doi.org/10.1172/jci.insight.95456)

Mraz M \& Haluzik M 2014 The role of adipose tissue immune cells in obesity and low-grade inflammation. Journal of Endocrinology $\mathbf{2 2 2}$ R113-R127. (https://doi.org/10.1530/JOE-14-0283)

Mraz M, Cinkajzlova A, Klouckova J, Lacinova Z, Kratochvilova H, Lips M, Porizka M, Kopecky P, Lindner J, Kotulak T, et al. 2019a Dendritic cells in subcutaneous and epicardial adipose tissue of subjects with type 2 diabetes, obesity, and coronary artery disease. Mediators of Inflammation 2019 5481725. (https://doi.org/10.1155/2019/5481725)

Mraz M, Cinkajzlova A, Klouckova J, Lacinova Z, Kratochvilova H, Lips M, Porizka M, Kopecky P, Pierzynova A, Kucera T, et al. 2019b Coronary artery disease is associated with an increased amount of $\mathrm{T}$ lymphocytes in human epicardial adipose tissue. Mediators of Inflammation 2019 4075086. (https://doi.org/10.1155/2019/4075086)

Nascimento H, Rocha S, Rego C, Mansilha HF, Quintanilha A, SantosSilva A \& Belo L 2010 Leukocyte count versus C-reactive protein levels https://joe.bioscientifica.com https://doi.org/10.1530/JOE-21-0159 (c) 2021 Society for Endocrinology Published by Bioscientifica Ltd. Printed in Great Britain 
in obese Portuguese patients aged 6-12 years old. Open Biochemistry Journal 4 72-76. (https://doi.org/10.2174/1874091X01004010072)

Niccoli G, Calvieri C, Flego D, Scalone G, Imaeva A, Sabato V, Schiavino D, Liuzzo G \& Crea F 2015 Allergic inflammation is associated with coronary instability and a worse clinical outcome after acute myocardial infarction. Circulation: Cardiovascular Interventions $\mathbf{8}$ e002554. (https://doi.org/10.1161/CIRCINTERVENTIONS.115.002554)

Nishimura S, Manabe I, Nagasaki M, Eto K, Yamashita H, Ohsugi M, Otsu M, Hara K, Ueki K, Sugiura S, et al. 2009 CD8+ effector T cells contribute to macrophage recruitment and adipose tissue inflammation in obesity. Nature Medicine 15 914-920. (https://doi. org/10.1038/nm.1964)

Nishimura S, Manabe I, Takaki S, Nagasaki M, Otsu M, Yamashita H, Sugita J, Yoshimura K, Eto K, Komuro I, et al. 2013 Adipose natural regulatory $\mathrm{B}$ cells negatively control adipose tissue inflammation. Cell Metabolism 18 759-766. (https://doi.org/10.1016/j.cmet.2013.09.017)

Nussbaum JC, Van Dyken SJ, von Moltke J, Cheng LE, Mohapatra A, Molofsky AB, Thornton EE, Krummel MF, Chawla A, Liang HE, et al. 2013 Type 2 innate lymphoid cells control eosinophil homeostasis. Nature 502 245-248. (https://doi.org/10.1038/nature12526)

Odegaard JI, Ricardo-Gonzalez RR, Goforth MH, Morel CR, Subramanian V, Mukundan L, Red Eagle A, Vats D, Brombacher F, Ferrante AW, et al. 2007 Macrophage-specific PPARgamma controls alternative activation and improves insulin resistance. Nature $\mathbf{4 4 7}$ 1116-1120. (https://doi. org/10.1038/nature05894)

Olson NC, Doyle MF, Jenny NS, Huber SA, Psaty BM, Kronmal RA \& Tracy RP 2013 Decreased naive and increased memory CD4(+) T cells are associated with subclinical atherosclerosis: the multi-ethnic study of atherosclerosis. PLoS ONE 8 e71498. (https://doi.org/10.1371/journal. pone.0071498)

O'Sullivan TE, Rapp M, Fan X, Weizman OE, Bhardwaj P, Adams NM, Walzer T, Dannenberg AJ \& Sun JC 2016 Adipose-resident group 1 innate lymphoid cells promote obesity-associated insulin resistance. Immunity 45 428-441. (https://doi.org/10.1016/j.immuni.2016.06.016)

Pacifico L, Di Renzo L, Anania C, Osborn JF, Ippoliti F, Schiavo E \& Chiesa C 2006 Increased T-helper interferon-gamma-secreting cells in obese children. European Journal of Endocrinology 154 691-697. (https://doi. org/10.1530/eje.1.02138)

Park YJ, Park J, Huh JY, Hwang I, Choe SS \& Kim JB 2018 Regulatory roles of invariant natural killer $\mathrm{T}$ cells in adipose tissue inflammation: defenders against obesity-induced metabolic complications. Frontiers in Immunology 9 1311. (https://doi.org/10.3389/fimmu.2018.01311)

Patel O, Pellicci DG, Gras S, Sandoval-Romero ML, Uldrich AP, Mallevaey T, Clarke AJ, Le Nours J, Theodossis A, Cardell SL, et al. 2012 Recognition of CD1d-sulfatide mediated by a type II natural killer T cell antigen receptor. Nature Immunology 13 857-863. (https://doi.org/10.1038/ ni.2372)

Paul VS, Paul CM \& Kuruvilla S 2016 Quantification of various inflammatory cells in advanced atherosclerotic plaques. Journal of Clinical and Diagnostic Research 10 EC35-38. (https://doi.org/10.7860/ JCDR/2016/19354.7879)

Pearce EL \& Pearce EJ 2013 Metabolic pathways in immune cell activation and quiescence. Immunity 38 633-643. (https://doi.org/10.1016/j. immuni.2013.04.005)

Pecht T, Gutman-Tirosh A, Bashan N \& Rudich A 2014 Peripheral blood leucocyte subclasses as potential biomarkers of adipose tissue inflammation and obesity subphenotypes in humans. Obesity Reviews 15 322-337. (https://doi.org/10.1111/obr.12133)

Perez LM, Pareja-Galeano H, Sanchis-Gomar F, Emanuele E, Lucia A \& Galvez BG 2016 'Adipaging': ageing and obesity share biological hallmarks related to a dysfunctional adipose tissue. Journal of Physiology 594 3187-3207. (https://doi.org/10.1113/JP271691)

Qiu Y, Nguyen KD, Odegaard JI, Cui X, Tian X, Locksley RM, Palmiter RD \& Chawla A 2014 Eosinophils and type 2 cytokine signaling in macrophages orchestrate development of functional beige fat. Cell 157 1292-1308. (https://doi.org/10.1016/j.cell.2014.03.066)
Revelo XS, Tsai S, Lei H, Luck H, Ghazarian M, Tsui H, Shi SY, Schroer S, Luk CT, Lin GH, et al. 2015 Perforin is a novel immune regulator of obesity-related insulin resistance. Diabetes 64 90-103. (https://doi. org/10.2337/db13-1524)

Reynolds CM, McGillicuddy FC, Harford KA, Finucane OM, Mills KH \& Roche HM 2012 Dietary saturated fatty acids prime the NLRP3 inflammasome via TLR4 in dendritic cells-implications for dietinduced insulin resistance. Molecular Nutrition and Food Research 56 1212-1222. (https://doi.org/10.1002/mnfr.201200058)

Rocha VZ, Folco EJ, Sukhova G, Shimizu K, Gotsman I, Vernon AH \& Libby P 2008 Interferon-gamma, a Th1 cytokine, regulates fat inflammation: a role for adaptive immunity in obesity. Circulation Research 103 467-476. (https://doi.org/10.1161/ CIRCRESAHA.108.177105)

Rogero MM \& Calder PC 2018 Obesity, inflammation, toll-like receptor 4 and fatty acids. Nutrients 10 432. (https://doi.org/10.3390/ nu10040432)

Roh JS \& Sohn DH 2018 Damage-associated molecular patterns in inflammatory diseases. Immune Network 18 e27. (https://doi. org/10.4110/in.2018.18.e27)

Romagnani S 1999 Th1/Th2 cells. Inflammatory Bowel Diseases 5 285-294. (https://doi.org/10.1097/00054725-199911000-00009)

Rosenfeld SM, Perry HM, Gonen A, Prohaska TA, Srikakulapu P, Grewal S, Das D, McSkimming C, Taylor AM, Tsimikas S, et al. 2015 B-1b cells secrete atheroprotective IgM and attenuate atherosclerosis. Circulation Research 117 e28-e39. (https://doi.org/10.1161/ CIRCRESAHA.117.306044)

Rossi A \& Lord J 2013a Adiponectin inhibits neutrophil phagocytosis of Escherichia coli by inhibition of PKB and ERK 1/2 MAPK signalling and Mac-1 activation. PLoS ONE 8 e69108. (https://doi.org/10.1371/journal. pone.0069108)

Rossi A \& Lord JM 2013b Adiponectin inhibits neutrophil apoptosis via activation of AMP kinase, PKB and ERK 1/2 MAP kinase. Apoptosis 18 1469-1480. (https://doi.org/10.1007/s10495-013-0893-8)

Rouault C, Pellegrinelli V, Schilch R, Cotillard A, Poitou C, Tordjman J, Sell H, Clement K \& Lacasa D 2013 Roles of chemokine ligand-2 (CXCL2) and neutrophils in influencing endothelial cell function and inflammation of human adipose tissue. Endocrinology 154 1069-1079. (https://doi.org/10.1210/en.2012-1415)

Saigusa R, Winkels H \& Ley K 2020 T cell subsets and functions in atherosclerosis. Nature Reviews: Cardiology 17 387-401. (https://doi. org/10.1038/s41569-020-0352-5)

Samsell L, Regier M, Walton C \& Cottrell L 2014 Importance of android/ gynoid fat ratio in predicting metabolic and cardiovascular disease risk in normal weight as well as overweight and obese children. Journal of Obesity 2014 846578. (https://doi.org/10.1155/2014/846578)

Sato M, Kawakami T, Kadota Y, Mori M \& Suzuki S 2013 Obesity and metallothionein. Current Pharmaceutical Biotechnology 14 432-440. (https://doi.org/10.2174/1389201011314040008)

Satoh M, Andoh Y, Clingan CS, Ogura H, Fujii S, Eshima K, Nakayama T, Taniguchi M, Hirata N, Ishimori N, et al. 2012 Type II NKT cells stimulate diet-induced obesity by mediating adipose tissue inflammation, steatohepatitis and insulin resistance. PLOS ONE 7 e30568. (https://doi.org/10.1371/journal.pone.0030568)

Schipper HS, Rakhshandehroo M, van de Graaf SF, Venken K, Koppen A, Stienstra R, Prop S, Meerding J, Hamers N, Besra G, et al. 2012 Natural killer $\mathrm{T}$ cells in adipose tissue prevent insulin resistance. Journal of Clinical Investigation 122 3343-3354. (https://doi.org/10.1172/ JCI62739)

Shah TJ, Leik CE \& Walsh SW 2010 Neutrophil infiltration and systemic vascular inflammation in obese women. Reproductive Sciences $\mathbf{1 7}$ 116-124. (https://doi.org/10.1177/1933719109348252)

Shapiro H, Pecht T, Shaco-Levy R, Harman-Boehm I, Kirshtein B, Kuperman Y, Chen A, Blüher M, Shai I \& Rudich A 2013 Adipose tissue foam cells are present in human obesity. Journal of Clinical Endocrinology and Metabolism 98 1173-1181. (https://doi.org/10.1210/jc.2012-2745) https://joe.bioscientifica.com https://doi.org/10.1530/JOE-21-0159 (c) 2021 Society for Endocrinology Published by Bioscientifica Ltd. Printed in Great Britain 
Shirakawa K, Yan X, Shinmura K, Endo J, Kataoka M, Katsumata Y, Yamamoto T, Anzai A, Isobe S, Yoshida N, et al. 2016 Obesity accelerates $\mathrm{T}$ cell senescence in murine visceral adipose tissue. Journal of Clinical Investigation 126 4626-4639. (https://doi.org/10.1172/JCI88606)

Sieweke MH \& Allen JE 2013 Beyond stem cells: self-renewal of differentiated macrophages. Science 342 1242974. (https://doi. org/10.1126/science.1242974)

Smyth MJ, Cretney E, Kelly JM, Westwood JA, Street SE, Yagita H, Takeda K, van Dommelen SL, Degli-Esposti MA \& Hayakawa Y 2005 Activation of NK cell cytotoxicity. Molecular Immunology 42 501-510. (https://doi. org/10.1016/j.molimm.2004.07.034)

Sojka DK \& Fowell DJ 2011 Regulatory T cells inhibit acute IFN-gamma synthesis without blocking T-helper cell type 1 (Th1) differentiation via a compartmentalized requirement for IL-10. PNAS 108 18336-18341. (https://doi.org/10.1073/pnas.1110566108)

Soylu K, Gulel O, Yucel H, Yuksel S, Aksan G, Soylu Aİ, Demircan S, Yilmaz O \& Sahin M 2014 The effect of blood cell count on coronary flow in patients with coronary slow flow phenomenon. Pakistan Journal of Medical Sciences 30 936-941. (https://doi.org/10.12669/ pjms.305.4935)

Srikakulapu P \& McNamara CA 2020 B lymphocytes and adipose tissue inflammation. Arteriosclerosis, Thrombosis, and Vascular Biology 40 1110-1122. (https://doi.org/10.1161/ATVBAHA.119.312467)

Stefanovic-Racic M, Yang X, Turner MS, Mantell BS, Stolz DB, Sumpter TL, Sipula IJ, Dedousis N, Scott DK, Morel PA, et al. 2012 Dendritic cells promote macrophage infiltration and comprise a substantial proportion of obesity-associated increases in CD11c+ cells in adipose tissue and liver. Diabetes 61 2330-2339. (https://doi.org/10.2337/db111523)

Stegelmeier AA, van Vloten JP, Mould RC, Klafuric EM, Minott JA, Wootton SK, Bridle BW \& Karimi K 2019 Myeloid cells during viral infections and inflammation. Viruses 11 168. (https://doi.org/10.3390/ v11020168)

Steinman RM 2012 Decisions about dendritic cells: past, present, and future. Annual Review of Immunology 30 1-22. (https://doi.org/10.1146/ annurev-immunol-100311-102839)

Subramanian S, Goodspeed L, Wang S, Ding Y, O’Brien KD, Getz GS, Chait A \& Reardon CA 2018 Deficiency of invariant natural killer T cells does not protect against obesity but exacerbates atherosclerosis in Ldlr(-/-) mice. International Journal of Molecular Sciences 19 510. (https:// doi.org/10.3390/ijms19020510)

Sundara Rajan S \& Longhi MP 2016 Dendritic cells and adipose tissue. Immunology 149 353-361. (https://doi.org/10.1111/imm.12653)

Surendar J, Frohberger SJ, Karunakaran I, Schmitt V, Stamminger W, Neumann AL, Wilhelm C, Hoerauf A \& Hübner MP 2019 Adiponectin limits IFN- $\gamma$ and IL-17 producing CD 4 T cells in obesity by restraining cell intrinsic glycolysis. Frontiers in Immunology 10 2555. (https://doi. org/10.3389/fimmu.2019.02555)

Tamura T, Tailor P, Yamaoka K, Kong HJ, Tsujimura H, O’Shea JJ, Singh H \& Ozato K 2005 IFN regulatory factor- 4 and -8 govern dendritic cell subset development and their functional diversity. Journal of Immunology 174 2573-2581. (https://doi.org/10.4049/jimmunol.174.5.2573)

Tiemessen MM, Jagger AL, Evans HG, van Herwijnen MJ, John S \& Taams LS 2007 CD4+CD25+Foxp3+ regulatory T cells induce alternative activation of human monocytes/macrophages. PNAS 104 19446-19451. (https://doi.org/10.1073/pnas.0706832104)

Toyama K, Sugiyama S, Oka H, Iwasaki Y, Sumida H, Tanaka T, Tayama S, Jinnouchi H \& Ogawa H 2012 Combination treatment of rosuvastatin or atorvastatin, with regular exercise improves arterial wall stiffness in patients with coronary artery disease. PLOS ONE 7 e41369. (https://doi. org/10.1371/journal.pone.0041369)

Uchida Y, Uchida Y, Shimoyama E, Hiruta N, Kishimoto T \& Watanabe S 2017 Human pericoronary adipose tissue as storage and possible supply site for oxidized low-density lipoprotein and high-density lipoprotein in coronary artery. Journal of Cardiology 69 236-244. (https://doi. org/10.1016/j.jjcc.2016.03.015) van der Wal AC, Das PK, Bentz van de Berg D, van der Loos CM \& Becker AE 1989 Atherosclerotic lesions in humans. In situ immunophenotypic analysis suggesting an immune mediated response. Laboratory Investigation 61 166-170.

Verdoia M, Schaffer A, Cassetti E, Di Giovine G, Marino P, Suryapranata H \& De Luca G 2015 Absolute eosinophils count and the extent of coronary artery disease: a single centre cohort study. Journal of Thrombosis and Thrombolysis 39 459-466. (https://doi.org/10.1007/ s11239-014-1120-3)

Verhagen SN, Vink A, van der Graaf Y \& Visseren FL 2012 Coronary perivascular adipose tissue characteristics are related to atherosclerotic plaque size and composition. A post-mortem study. Atherosclerosis 225 99-104. (https://doi.org/10.1016/j. atherosclerosis.2012.08.031)

Vianello E, Dozio E, Arnaboldi F, Marazzi MG, Martinelli C, Lamont J, Tacchini L, Sigruner A, Schmitz G \& Corsi Romanelli MM 2016 Epicardial adipocyte hypertrophy: association with M1-polarization and toll-like receptor pathways in coronary artery disease patients. Nutrition, Metabolism, and Cardiovascular Diseases 26 246-253. (https:// doi.org/10.1016/j.numecd.2015.12.005)

Vicenova B, Vopalensky V, Burysek L \& Pospisek M 2009 Emerging role of interleukin-1 in cardiovascular diseases. Physiological Research $\mathbf{5 8}$ 481-498. (https://doi.org/10.33549/physiolres.931673)

Vijay J, Gauthier MF, Biswell RL, Louiselle DA, Johnston JJ, Cheung WA, Belden B, Pramatarova A, Biertho L, Gibson M, et al. 2020 Single-cell analysis of human adipose tissue identifies depot and disease specific cell types. Nature Metabolism 2 97-109. (https://doi.org/10.1038/ s42255-019-0152-6)

Virgolini I, Li SR, Yang Q, Koller E, Sperr WR, Leimer M, Angelberger P, Nimpf J, Schneider W \& Valent P 1995 Characterization of LDL and VLDL binding sites on human basophils and mast cells. Arteriosclerosis, Thrombosis, and Vascular Biology 15 17-26. (https://doi.org/10.1161/01. atv.15.1.17)

Volpato S, Guralnik JM, Ferrucci L, Balfour J, Chaves P, Fried LP \& Harris TB 2001 Cardiovascular disease, interleukin-6, and risk of mortality in older women: the women's health and aging study. Circulation 103 947-953. (https://doi.org/10.1161/01.cir.103.7.947)

Vu DM, Tai A, Tatro JB, Karas RH, Huber BT \& Beasley D 2014 gammadeltaT cells are prevalent in the proximal aorta and drive nascent atherosclerotic lesion progression and neutrophilia in hypercholesterolemic mice. PLOS ONE 9 e109416. (https://doi. org/10.1371/journal.pone.0109416)

Watanabe S, Alexander M, Misharin AV \& Budinger GRS 2019a The role of macrophages in the resolution of inflammation. Journal of Clinical Investigation 129 2619-2628. (https://doi.org/10.1172/JCI124615)

Watanabe Y, Nagai Y, Honda H, Okamoto N, Yanagibashi T, Ogasawara M, Yamamoto S, Imamura R, Takasaki I, Hara H, et al. $2019 \mathrm{~b}$ Bidirectional crosstalk between neutrophils and adipocytes promotes adipose tissue inflammation. FASEB Journal 33 11821-11835. (https://doi.org/10.1096/ fj.201900477RR)

Weisberg SP, McCann D, Desai M, Rosenbaum M, Leibel RL \& Ferrante Jr AW 2003 Obesity is associated with macrophage accumulation in adipose tissue. Journal of Clinical Investigation 112 1796-1808. (https:// doi.org/10.1172/JCI19246)

Wensveen FM, Jelencic V, Valentic S, Sestan M, Wensveen TT, Theurich S, Glasner A, Mendrila D, Stimac D, Wunderlich FT, et al. 2015 NK cells link obesity-induced adipose stress to inflammation and insulin resistance. Nature Immunology 16 376-385. (https://doi.org/10.1038/ ni.3120)

Willems S, Vink A, Bot I, Quax PH, de Borst GJ, de Vries JP, van de Weg SM, Moll FL, Kuiper J, Kovanen PT, et al. 2013 Mast cells in human carotid atherosclerotic plaques are associated with intraplaque microvessel density and the occurrence of future cardiovascular events. European Heart Journal 34 3699-3706. (https://doi.org/10.1093/eurheartj/eht186)

Winer S, Chan Y, Paltser G, Truong D, Tsui H, Bahrami J, Dorfman R, Wang Y, Zielenski J, Mastronardi F, et al. 2009 Normalization of obesity- https://joe.bioscientifica.com

https://doi.org/10.1530/JOE-21-0159 (c) 2021 Society for Endocrinology Published by Bioscientifica Ltd. Printed in Great Britain 
associated insulin resistance through immunotherapy. Nature Medicine 15 921-929. (https://doi.org/10.1038/nm.2001)

Winer DA, Winer S, Shen L, Wadia PP, Yantha J, Paltser G, Tsui H, Wu P, Davidson MG, Alonso MN, et al. 2011 B cells promote insulin resistance through modulation of $\mathrm{T}$ cells and production of pathogenic $\operatorname{IgG}$ antibodies. Nature Medicine 17 610-617. (https://doi.org/10.1038/nm.2353)

Wong JB, Hewitt SL, Heltemes-Harris LM, Mandal M, Johnson K, Rajewsky K, Koralov SB, Clark MR, Farrar MA \& Skok JA 2019 B-1a cells acquire their unique characteristics by bypassing the pre-BCR selection stage. Nature Communications 10 4768. (https://doi.org/10.1038/s41467019-12824-z)

Wortis HH, Teutsch M, Higer M, Zheng J \& Parker DC 1995 B-cell activation by crosslinking of surface IgM or ligation of CD40 involves alternative signal pathways and results in different B-cell phenotypes. PNAS 92 3348-3352. (https://doi.org/10.1073/pnas.92.8.3348)

Wouters K, Kusters YHAM, Bijnen M, Wetzels S, Zhang X, Linssen PBC, Gaens K, Houben AJHM, Joris PJ, Plat J, et al. 2020 NK cells in human visceral adipose tissue contribute to obesity-associated insulin resistance through low-grade inflammation. Clinical and Translational Medicine 10 e192. (https://doi.org/10.1002/ctm2.192)

Wu L, D’Amico A, Hochrein H, O'Keeffe M, Shortman K \& Lucas K 2001 Development of thymic and splenic dendritic cell populations from different hemopoietic precursors. Blood 98 3376-3382. (https://doi. org/10.1182/blood.v98.12.3376)

Wu KK, Cheung SW \& Cheng KK 2020 NLRP3 inflammasome activation in adipose tissues and its implications on metabolic diseases. International Journal of Molecular Sciences 21 4181. (https://doi.org/10.3390/ ijms21114184)

Xu X, Su S, Wang X, Barnes V, De Miguel C, Ownby D, Pollock J, Snieder H, Chen W \& Wang X 2015 Obesity is associated with more activated neutrophils in African American male youth. International Journal of Obesity 39 26-32. (https://doi.org/10.1038/ijo.2014.194)

Ying W, Wollam J, Ofrecio JM, Bandyopadhyay G, El Ouarrat D, Lee YS, Oh DY, Li P, Osborn O \& Olefsky JM 2017 Adipose tissue B2 cells promote insulin resistance through leukotriene LTB4/LTB4R1 signaling. Journal of Clinical Investigation 127 1019-1030. (https://doi. org/10.1172/JCI90350)

Yona S, Kim KW, Wolf Y, Mildner A, Varol D, Breker M, Strauss-Ayali D, Viukov S, Guilliams M, Misharin A, et al. 2013 Fate mapping reveals origins and dynamics of monocytes and tissue macrophages under homeostasis. Immunity 38 79-91. (https://doi.org/10.1016/j. immuni.2012.12.001)

Zeng C, Shi X, Zhang B, Liu H, Zhang L, Ding W \& Zhao Y 2012 The imbalance of Th17/Th1/Tregs in patients with type 2 diabetes: relationship with metabolic factors and complications. Journal of Molecular Medicine 90 175-186. (https://doi.org/10.1007/s00109-0110816-5)

Zeyda M, Farmer D, Todoric J, Aszmann O, Speiser M, Gyori G, Zlabinger GJ \& Stulnig TM 2007 Human adipose tissue macrophages are of an antiinflammatory phenotype but capable of excessive pro-inflammatory mediator production. International Journal of Obesity 31 1420-1428. (https://doi.org/10.1038/sj.ijo.0803632)

Ziegler-Heitbrock L 2007 The CD14+ CD16+ blood monocytes: their role in infection and inflammation. Journal of Leukocyte Biology 81 584-592. (https://doi.org/10.1189/jlb.0806510)

Zlotnikov-Klionsky Y, Nathansohn-Levi B, Shezen E, Rosen C, Kagan S, Bar-On L, Jung S, Shifrut E, Reich-Zeliger S, Friedman N, et al. 2015 Perforin-positive dendritic cells exhibit an immuno-regulatory role in metabolic syndrome and autoimmunity. Immunity 43 776-787. (https://doi.org/10.1016/j.immuni.2015.08.015)

Zuniga LA, Shen WJ, Joyce-Shaikh B, Pyatnova EA, Richards AG, Thom C, Andrade SM, Cua DJ, Kraemer FB \& Butcher EC 2010 IL-17 regulates adipogenesis, glucose homeostasis, and obesity. Journal of Immunology 185 6947-6959. (https://doi.org/10.4049/jimmunol.1001269)

Zuo J, Shan Z, Zhou L, Yu J, Liu X \& Gao Y 2015 Increased CD160 expression on circulating natural killer cells in atherogenesis. Journal of Translational Medicine 13 188. (https://doi.org/10.1186/s12967-0150564-3)

Received in final form 2 September 2021

Accepted 24 September 2021

Accepted Manuscript published online 24 September 2021 (c) 2021 Society for Endocrinology Published by Bioscientifica Ltd. Printed in Great Britain 